

\section{Supplement to Water-Resources Investigations Report 99-4122, Lake-Level Frequency Analysis for the Waubay Lakes Chain, Northeastern South Dakota}

By Colin A. Niehus, Aldo V. Vecchia, and Ryan F. Thompson

Water-Resources Investigations Report 99-4251

Prepared in cooperation with the Federal Emergency Management Agency 


\section{U.S. Department of the Interior \\ Bruce Babbitt, Secretary}

\section{U.S. Geological Survey}

Charles G. Groat, Director

The use of firm, trade, and brand names in this report is for identification purposes only and does not constitute endorsement by the U.S. Geological Survey.

Rapid City, South Dakota: 1999

For additional information write to:

\section{District Chief}

U.S. Geological Survey

1608 Mt. View Road

Rapid City, SD 57702

Copies of this report can be purchased from:

\section{U.S. Geological Survey}

Information Services

Box 25286

Denver, CO 80225-0286 


\section{CONTENTS}

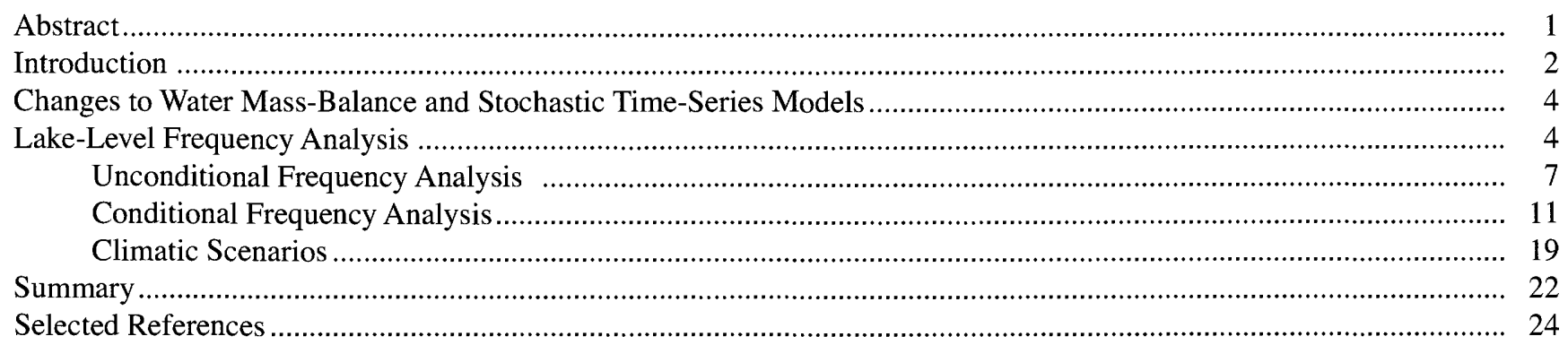

\section{ILLUSTRATIONS}

1. Map showing location of the study area

2. Schematic showing lake connections for Waubay Lakes Chain with the farm crossings removed at the outlet between Rush and Bitter Lakes.

3. Map showing outlet between Rush and Bitter Lakes

4. Graph showing rating curve for the outlet between Rush and Bitter Lakes with the farm crossings removed at the outlet between Rush and Bitter Lakes

5. Graph showing generated 20-year maximum lake levels for Waubay Lake using an unconditional frequency analysis with the farm crossings removed at the outlet between Rush and Bitter Lakes

6. Graph showing historic (water years 1963-99) and generated (water years 2000-49) annual maximum lake levels for Waubay Lake with the farm crossings removed at the outlet between Rush and Bitter Lakes

7-16. Graphs showing upper and lower probability bounds computed from 10,000 50-year traces from the water mass-balance model, with each trace starting October 1, 1999, and with the farm crossings removed at the outlet between Rush and Bitter Lakes for:

7. Bitter Lake

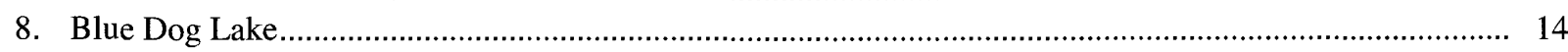

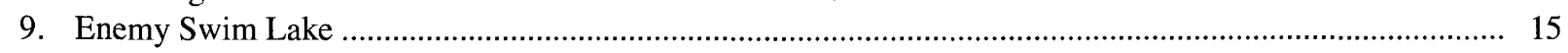

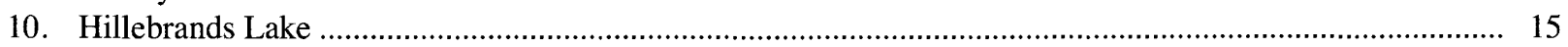

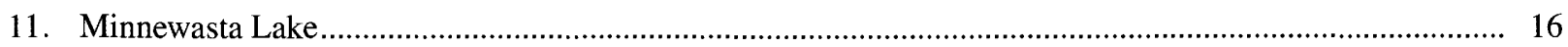

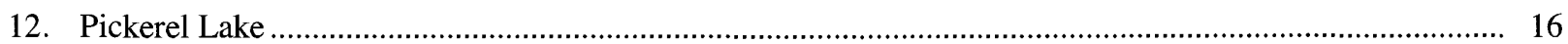

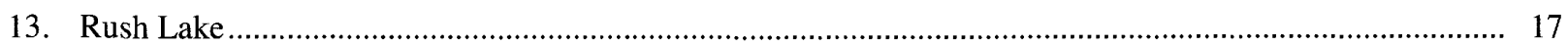

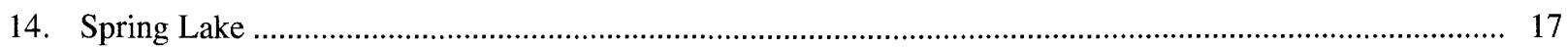

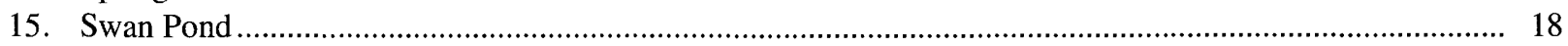

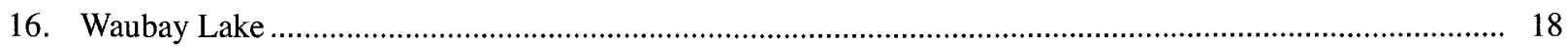

17. Graph showing simulated lake levels of Bitter Lake for selected 16-year climatic scenarios, starting with October 1, 1999, lake level and with the farm crossings removed at the outlet between Rush and Bitter Lakes .....

18. Graph showing simulated lake levels of Waubay Lake for selected 16-year climatic scenarios, starting with October 1, 1999, lake level and with the farm crossings removed at the outlet between Rush and Bitter Lakes ....

19. Graph showing probability bounds and selected 16-year scenario results for Waubay Lake, starting with October 1,1999, lake level and with the farm crossings removed at the outlet between Rush and Bitter Lakes ...... 


\section{TABLES}

1. Probability of high lake levels using an unconditional frequency analysis for the Waubay Lakes

Chain with the farm crossings removed at the outlet between Rush and Bitter Lakes

2. Probability of low lake levels using an unconditional frequency analysis for the Waubay Lakes

Chain with the farm crossings removed at the outlet between Rush and Bitter Lakes.....

3. Probability of Waubay Lake exceeding selected lake levels in each of the next 50 years, using

October 1, 1999, starting lake levels and with the farm crossings removed at the outlet

between Rush and Bitter Lakes

\section{PLATES}

[Plates are in pocket]

1. Probabilities of lake extents, based on October 1, 1999, starting lake levels and with the farm crossings removed at the outlet between Rush and Bitter Lakes

2. Lake extents in year 2015 for two climatic scenarios and for the 1-percent exceedance probability with the farm crossings removed at the outlet between Rush and Bitter Lakes

CONVERSION FACTORS AND VERTICAL DATUM

\begin{tabular}{rll} 
Multiply & By & To obtain \\
\hline cubic foot $\left(\mathrm{ft}^{3}\right)$ & 28.32 & cubic decimeter \\
cubic foot $\left(\mathrm{ft}^{3}\right)$ & 0.02832 & cubic meter \\
cubic foot per second $\left(\mathrm{ft}^{3} / \mathrm{s}\right)$ & 0.02832 & cubic meter per second \\
foot (ft) & 0.3048 & meter \\
inch (in.) & 2.54 & centimeter \\
inch (in.) & 25.4 & millimeter \\
\hline
\end{tabular}

Sea level: In this report, "sea level" refers to the National Geodetic Vertical Datum of 1929 (NGVD of 1929) - a geodetic datum derived from a general adjustment of the first-order level nets of both the United States and Canada, formerly called Sea Level Datum of 1929.

Water year: In U.S. Geological Survey reports, water year is the 12-month period, October 1 through September 30. The water year is designated by the calendar year in which it ends; thus, the water year ending September 30, 1999, is called the "1999 water year." 


\title{
Supplement to Water-Resources Investigations Report 99-4122, Lake-Level Frequency Analysis for the Waubay Lakes Chain, Northeastern South Dakota
}

\author{
By Colin A. Niehus, Aldo V. Vecchia, and Ryan F. Thompson
}

\section{ABSTRACT}

A supplement to a U.S. Geological Survey report was prepared to present lake-level frequency results for the Waubay Lakes Chain, northeastern South Dakota, incorporating a modified outlet between Rush and Bitter Lakes. The modification involved removal of two farm crossings from the drainage way between Rush and Bitter Lakes. The farm crossings were removed during July-August 1999 as a result of a court ruling. Water mass-balance and stochastic time-series models were revised to incorporate the modified outlet and also to change the starting lake levels to October 1, 1999.

The outlet elevation between the upstream lakes (Hillebrands Lake, Rush Lake, Spring Lake, Swan Pond, and Waubay Lake) and Bitter Lake was changed from an elevation of $1,803.6$ feet to 1,798.69 feet to reflect the modified outlet between Rush and Bitter Lakes. Two 24-inch culverts through an east-west township road embankment now control outflow from Rush Lake to Bitter Lake. At higher lake levels, outflow from Rush Lake to Bitter Lake is controlled by a 42-inch culvert through a railroad embankment.

Both an unconditional and a conditional lake-level frequency analysis were done. An unconditional frequency analysis estimates the frequencies of high or low lake levels for a long time period. A conditional frequency analysis estimates the frequencies of hypothetical future lake levels for a relatively short time period.
Because studies that relate to flood-risk-assessment or flood-mitigation alternatives usually are pertinent only for relatively short time periods into the future, conditional frequency analysis usually is more appropriate than unconditional frequency analysis.

The unconditional frequency analysis was performed for Bitter, Enemy Swim, Pickerel, and Waubay Lakes using 10,000 years of generated lake levels with the farm crossings removed at the outlet between Rush and Bitter Lakes. Waubay Lake was above an elevation of $1,811.0 \mathrm{ft}$, which is approximately equal to the closed-basin spill elevation to the Big Sioux River, 1 percent of the time (100 out of 10,000 years). However, only nine separate spill events with an average duration of 11 years occurred during the 10,000-year simulation period, giving an average return period of 1,111 years. Bitter Lake exceeded an elevation of $1,814.0 \mathrm{ft}$, which is high enough to result in large flows to the Big Sioux River, an average of once every 2,500 years and stayed above this elevation an average of 5 years before subsiding. The exceedance-level results for Blue Dog Lake, Hillebrands Lake, Minnewasta Lake, Rush Lake, Spring Lake, and Swan Pond are nearly identical to those for Waubay Lake.

The unconditional frequency analysis also shows that the recent high levels of the Waubay Lakes Chain occur relatively infrequently. For example, the peak lake level of Waubay Lake was about an elevation of $1,802.1 \mathrm{ft}$ during 1998 and 1999; however, based on model simulations, 
Waubay Lake only reaches this elevation an average of once every 154 years and stays above this elevation an average of 15 years before subsiding. Enemy Swim Lake reaches an elevation of $1,856.1 \mathrm{ft}$, which was exceeded in 1997 , an average of once every 500 years and stays above this elevation an average of 1 year before subsiding. Pickerel Lake reaches an elevation of $1,846.7 \mathrm{ft}$, which was equalled in 1997, an average of once every 500 years and stays above this elevation an average of 1 year before subsiding.

The conditional frequency analysis was performed for the 10 major lakes of the Waubay Lakes Chain using 10,000 simulated 50-year lakelevel traces, each starting on October 1,1999, with the farm crossings removed at the outlet between Rush and Bitter Lakes. The generated data can be used to estimate the probability of virtually any event that involves future lake levels.

The conditional frequency analysis for Bitter Lake, Blue Dog Lake, Hillebrands Lake, Minnewasta Lake, Rush Lake, Spring Lake, Swan Pond, and Waubay Lake indicates that the chance the lakes will continue to rise to the spill elevation with the Big Sioux River within the next 10 to 15 years is greater than 1 percent. Conversely, there is about a 1-percent chance that Hillebrands Lake, Spring Lake, Swan Pond, and Waubay Lake will return to levels comparable to historic 1960-92 levels in the next 25 years and that Bitter Lake will return to 1960-92 levels in the next 50 years. However, there is about a 10-percent chance that Blue Dog and Rush Lakes could return to historic 1960-92 levels within 10 years.

Because Enemy Swim and Pickerel Lakes spill frequently and never join with the downstream lakes, the conditional frequency analysis for these lakes shows that both lakes are unlikely to increase significantly over current levels, and both lakes could return to historic 1960-92 levels much sooner than the other lakes under a reversal of the current wet conditions.

The climatic scenarios analysis also was revised to account for the removal of the farm crossings at the outlet between Rush and Bitter Lakes and using October 1, 1999, starting conditions. The wet-wet scenario, representing two
1991-98 climatic segments, results in Bitter Lake, after 16 years, rising $21.4 \mathrm{ft}$ above the starting lake level and Waubay Lake rising $9.8 \mathrm{ft}$. The dry-dry scenario, representing two consecutive 1969-76 climatic segments, results in Bitter Lake, after 16 years, declining $3.9 \mathrm{ft}$ and Waubay Lake declining $14.7 \mathrm{ft}$.

The conditional frequency analysis performed for Waubay Lake with October 1, 1999, starting lake levels was compared to the scenario results. The five selected scenarios seemed to represent essentially the full range of hypothetical future lake levels. The lake levels after 16 years range from about the lower 1-percent probability bound for the dry-dry scenario to about the upper 0.2 -percent probability bound for the wet-wet scenario.

\section{INTRODUCTION}

A lake-level frequency analysis for the Waubay Lakes Chain in northeastern South Dakota was recently conducted by the U.S. Geological Survey (USGS) in cooperation with the Federal Emergency Management Agency (FEMA). Results are presented in USGS Water-Resources Investigations Report 99-4122 (WRIR 99-4122), entitled "Lake-Level Frequency Analysis for the Waubay Lakes Chain, Northeastern South Dakota" (Niehus and others, 1999).

The purpose of the study was to obtain information on high lake levels, possible causes of the high lake levels, and probabilities of hypothetical future lake levels of 10 lakes in the Waubay Lakes Chain (fig. 1). Those lakes are Bitter Lake, Blue Dog Lake, Enemy Swim Lake, Hillebrands Lake, Minnewasta Lake, Pickerel Lake, Rush Lake, Spring Lake, Swan Pond, and Waubay Lake.

The outlet between Rush and Bitter Lakes was modified during July-August 1999 as a result of a July 6, 1999, ruling by the Fifth Judicial Circuit Court that specified removal of two farm crossings in the area. Consequently, lake-level frequency results needed to be revised. The purpose of this report is to present the revised results. A description of the study area, and of a water mass-balance model and a stochastic time-series model that were developed for the lake-level frequency analysis, are presented in WRIR 99-4122. 


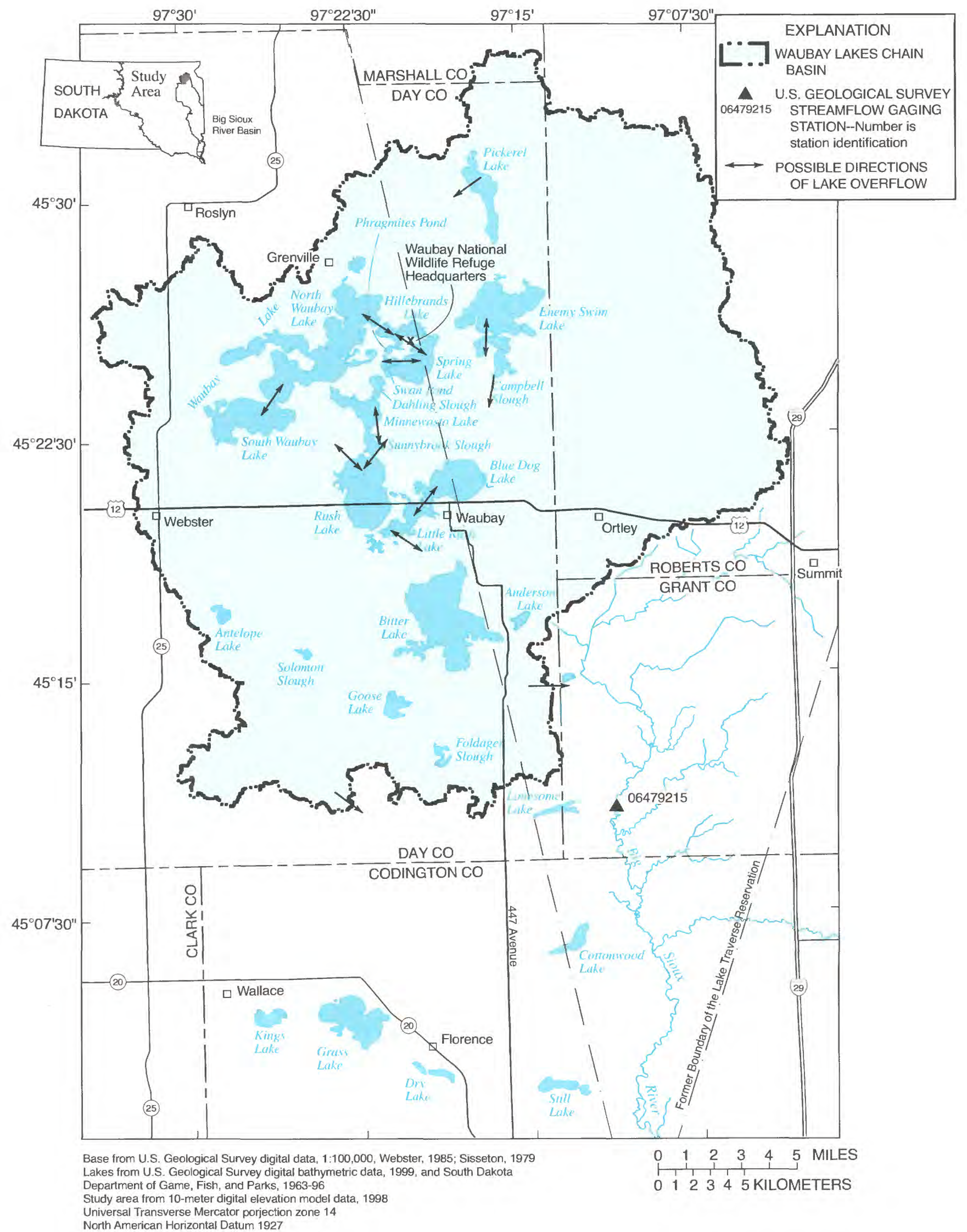

Figure 1. Location of the study area. 


\section{CHANGES TO WATER MASS-BALANCE AND STOCHASTIC TIME-SERIES MODELS}

Changes to the water mass-balance and stochastic time-series models involved incorporating the modified outlet between Rush and Bitter Lakes and also using October 1, 1999, starting lake levels instead of October 1, 1998, starting lake levels. All other information concerning the models is described in WRIR 99-4122.

The elevations of the outlets between lakes in the Waubay Lakes Chain are shown in figure 2. The outlet elevation between the upstream lakes (Hillebrands Lake, Rush Lake, Spring Lake, Swan Pond, and Waubay Lake) and Bitter Lake was changed from an elevation of $1,803.6 \mathrm{ft}$ to an elevation of $1,798.69 \mathrm{ft}$ to reflect the modified outlet between Rush and Bitter Lakes. Prior to July 1999, the outflow from Rush Lake through Little Rush Lake to Bitter Lake was by overtopping of two farm crossings (shown in figure 3 ). The Fifth Judicial Circuit Court ruled on July 6, 1999, that the two farm crossings be removed by August 13, 1999. Outflow from Rush Lake to Bitter Lake is now controlled by two 24-in. culverts through an east-west township road embankment and at higher lake levels by a 42-in. culvert through the Burlington Northern Railroad embankment as shown in figure 3 . As a result of the subsequent removal of the two farm crossings during July-August 1999, the new spill elevation from Rush Lake to Bitter Lake is $1,798.69 \mathrm{ft}$. The water mass-balance model was revised to incorporate this change.

Empirical flow-rating equations could not be developed for Rush Lake to Bitter Lake and for Bitter Lake to the Big Sioux River because historic data are not available for spills. Therefore, the spill calculations were based on flow ratings supplied by the U.S. Army Corps of Engineers (USACE) (Doug Clemetson, written commun., 1999). A continuous curve (relating water-surface elevation to flow) was used to approximate the outlet rating curves for flow from Rush Lake to Bitter Lake. If Rush Lake is above an elevation of $1,811.5 \mathrm{ft}$, the railroad embankment (fig. 3 ) is overtopped and flow is assumed to be unimpeded; if Rush Lake is below $1,798.69 \mathrm{ft}$ (the spill elevation with Bitter Lake), no flow is allowed. Although an assumption is made that Bitter Lake will never spill into Rush Lake, if that situation does occur the water is allowed to flow from Bitter Lake to Rush Lake until the levels of the two lakes are equal or until the level of Bitter Lake is below the spill elevation.

The revised USACE flow ratings between Rush Lake and Bitter Lake are shown in figure 4. Three different rating curves are shown, depending on what controls the flow between Rush and Bitter Lakes (the east-west township road, the north-south county road, or the Burlington Northern Railroad). The rating used in the water mass-balance model is shown in red in figure 4. The assumption was made that the east-west township road is the control until the lake level reaches an elevation of $1,807.5 \mathrm{ft}$, when the railroad embankment becomes the control. An assumption was made that the north-south county road never is the control. It was assumed that the east-west township road will be maintained so that it is not breached, although some piping is occurring at the present time (September 1999) around the two 24 -in. culverts through the road embankment.

The water mass-balance and stochastic timeseries models are available at the USGS Subdistrict Office in Huron, S. Dak. These models simulate semiannual lake volumes of the 10 major lakes of the Waubay Lakes Chain using precipitation, evaporation, total inflow to the system, and starting lake levels as input. Lake levels that existed on September 13, 1999, were used to represent October 1, 1999, starting conditions.

\section{LAKE-LEVEL FREQUENCY ANALYSIS}

The frequencies of extreme high or low lake levels for the Waubay Lakes Chain were estimated using the stochastic time-series model as described in WRIR 99-4122 to generate inputs for the water massbalance model. Both an unconditional and a conditional lake-level frequency analysis were done. An unconditional frequency analysis estimates the frequencies of high or low lake levels for a long time period during which the lake levels cycle many times between wet and dry periods. The starting conditions at the beginning of the simulation period have no effect on the analysis because of the long simulation period. An unconditional frequency analysis is used to evaluate the frequency of an individual event, such as the historic lake-level rise for water years 1993-99, in the context of a much longer record. A conditional frequency analysis estimates the frequencies of hypothetical future lake levels for a relatively short time period, such as 50 years. Because of the short time period, the 


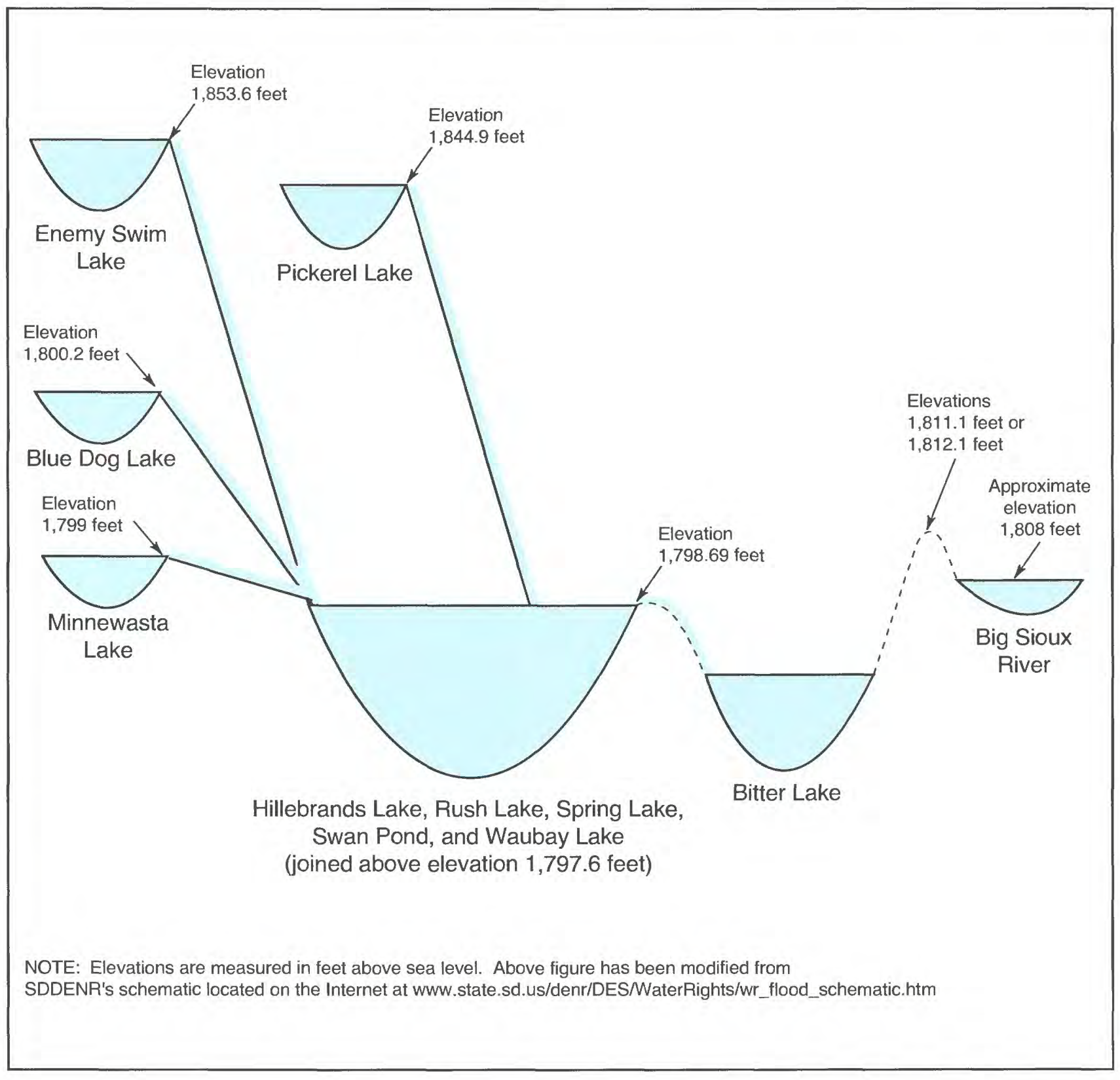

Figure 2. Lake connections for the Waubay Lakes Chain with the farm crossings removed at the outlet between Rush and Bitter Lakes. 


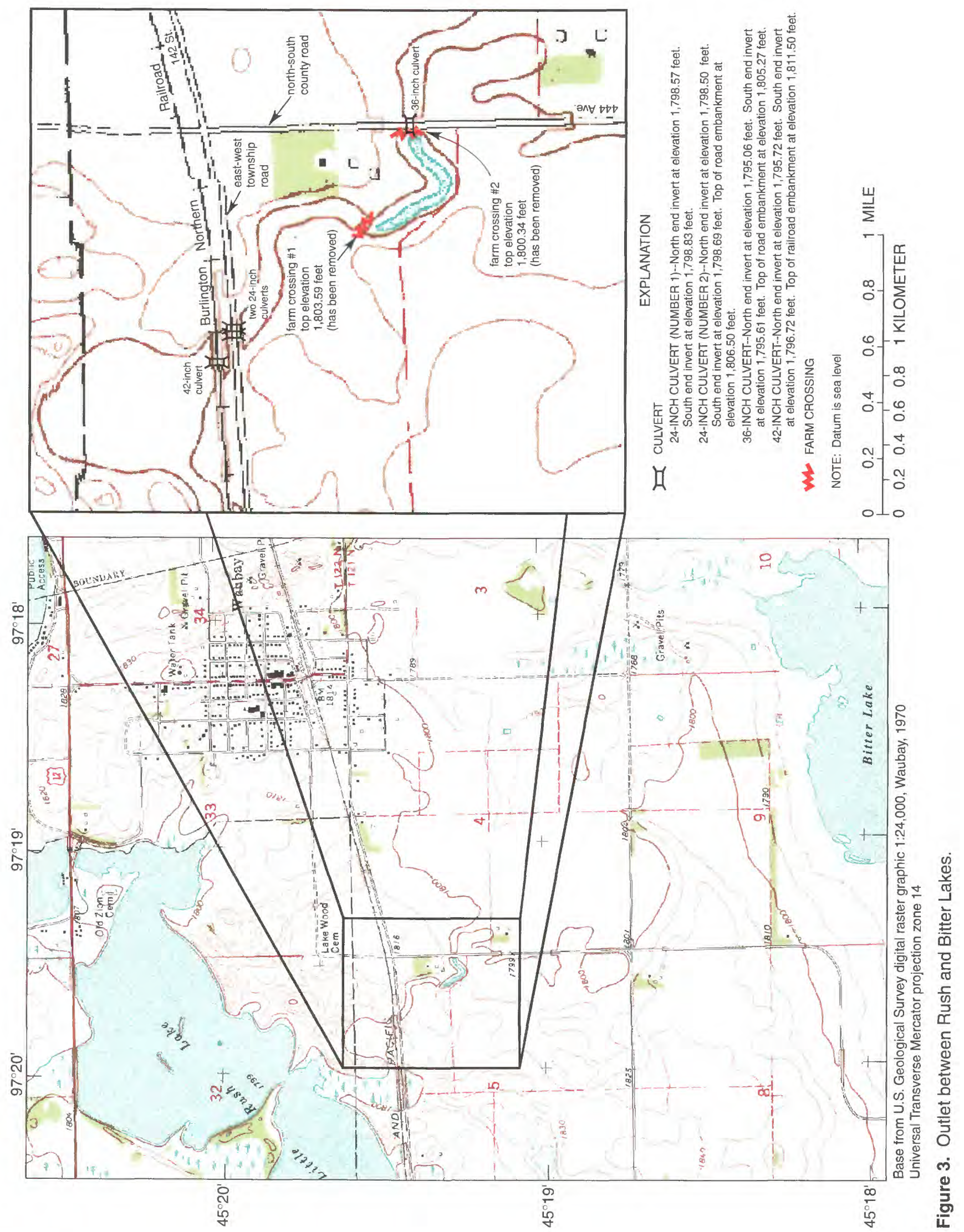




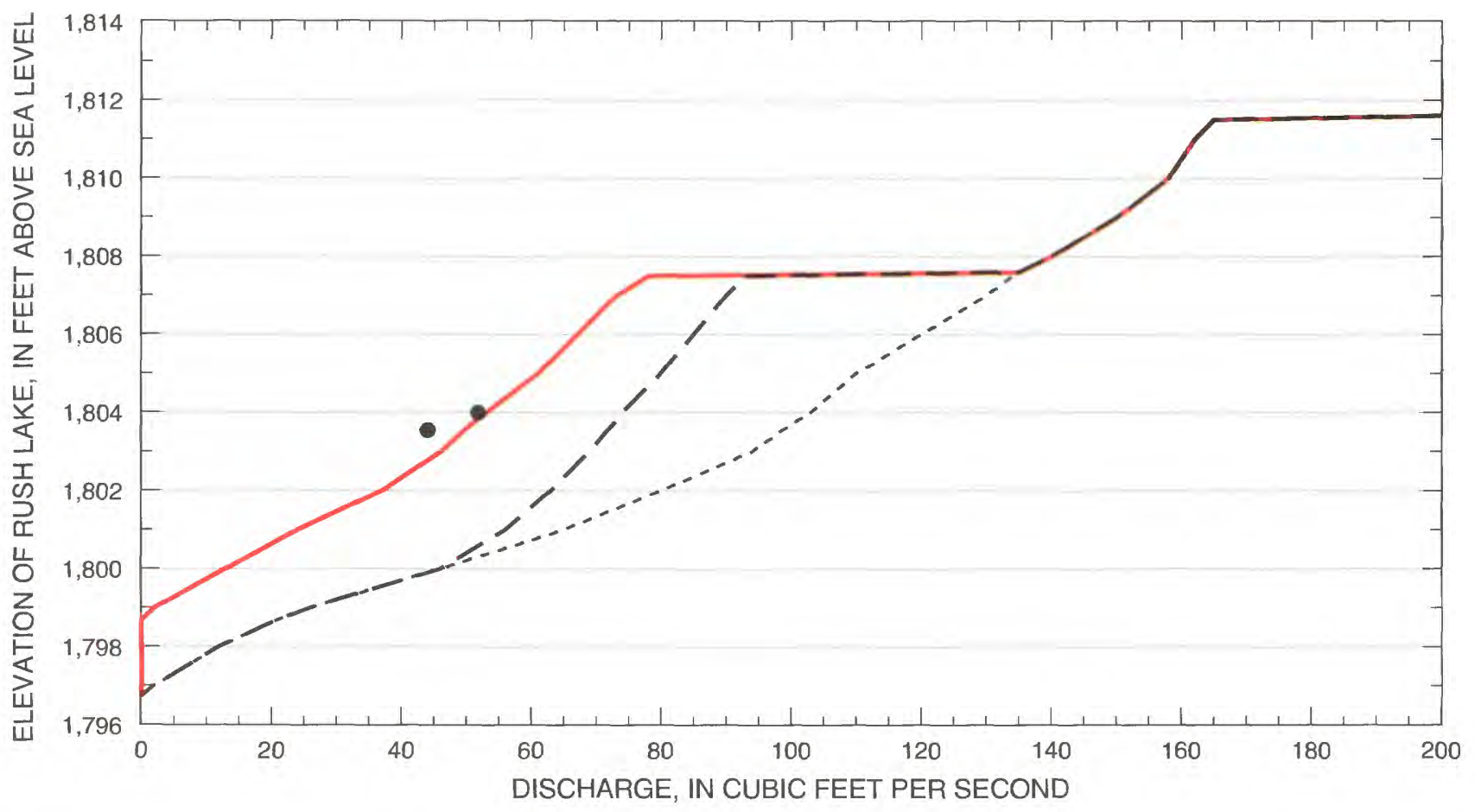

EXPLANATION

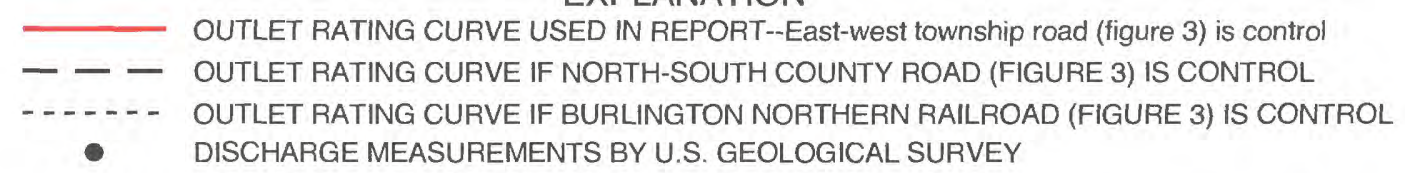

Figure 4. Rating curve for the outlet between Rush and Bitter Lakes with the farm crossings removed at the outlet between Rush and Bitter Lakes.

starting conditions at the beginning of the simulation period have an effect on the frequencies of the lake levels. Because studies that relate to flood-riskassessment or flood-mitigation alternatives usually are pertinent only for relatively short time periods into the future, a conditional frequency analysis usually is more appropriate than an unconditional frequency analysis.

\section{Unconditional Frequency Analysis}

An unconditional frequency analysis was performed for Bitter, Enemy Swim, Pickerel, and Waubay Lakes using 10,000 years of generated data with the two farm crossings removed at the outlet between Rush and Bitter Lakes. The generated data for Waubay Lake are shown in figure 5. To smooth some of the highfrequency variation in the data, the maximum lake levels for successive 20-year intervals are shown in the figure. Also shown is the (unconditional) 1-percent exceedance level, which is defined as the lake level above which 1 percent of the annual maximum lake levels lie. For Waubay Lake, the 1-percent exceedance level is at an elevation of $1,811.0 \mathrm{ft}$, which is approximately equal to the closed-basin spill elevation to the Big Sioux River. However, only nine separate spill events occurred during the 10,000-year simulation period, giving an average return period of 1,111 years. If the lake levels were independent from year to year (as usually is the case when considering annual stream discharges), the recurrence interval for the 1-percent exceedance level would be 1 divided by the exceedance probability, or 100 years. However, because of the high serial persistence in the lake levels, the return period corresponding to the 1-percent exceedance level is much longer than 100 years. The average duration of each event is the number of years the lake level is above an elevation of $1,811.0 \mathrm{ft}$ (100) divided by the number of occurrences (9). Thus, the lake level is above an elevation of $1,811.0 \mathrm{ft}$ an average of once every 1,111 years but stays above that level an average of 11 years per event. 


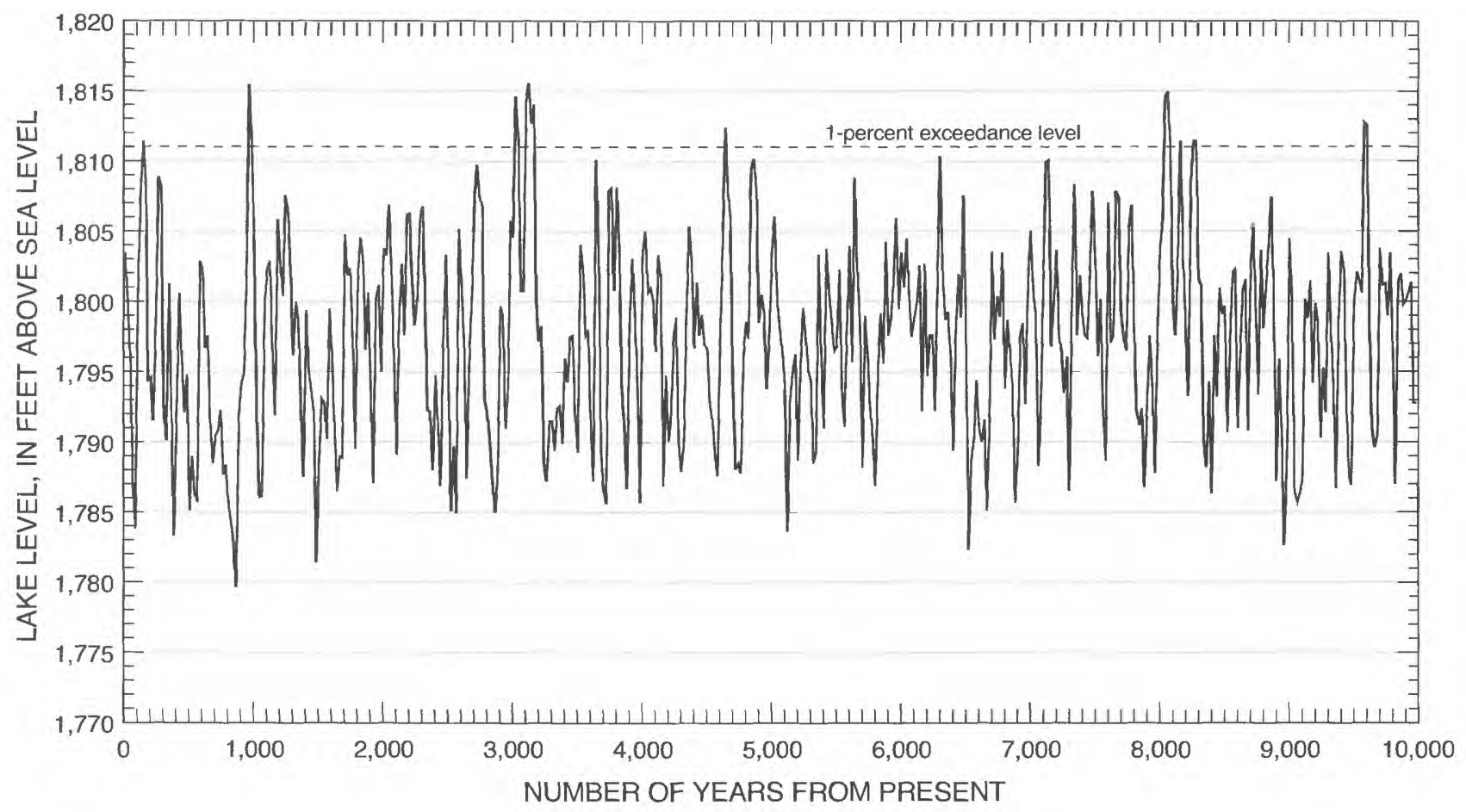

Figure 5. Generated 20-year maximum lake levels for Waubay Lake using an unconditional frequency analysis with the farm crossings removed at the outlet between Rush and Bitter Lakes.

The exceedance levels, average return periods, and average durations for selected exceedance probabilities for Bitter, Enemy Swim, Pickerel, and Waubay Lakes are shown in table 1. Bitter Lake exceeded an elevation of $1,814.0 \mathrm{ft}$, which is high enough to result in large flows to the Big Sioux River, an average of once every 2,500 years and stayed above this elevation an average of 5 years before subsiding. The exceedance levels for Hillebrands Lake, Rush Lake, Spring Lake, and Swan Pond are nearly identical to those for Waubay Lake because they are joined with Waubay Lake above an elevation of 1,797.6 ft (fig. 2). The exceedance-level results for Waubay Lake also are assumed to be identical to Blue Dog and Minnewasta Lakes because their outlet elevation with Waubay Lake is substantially lower than most of the exceedancelevel elevations shown in table 1.

On September 13, 1999, Bitter Lake was at an elevation of 1,792.05 ft, Enemy Swim Lake was at an elevation of $1,853.58 \mathrm{ft}$, Pickerel Lake was at an elevation of $1,845.54 \mathrm{ft}$, and Waubay Lake was at an elevation of 1,803.75 ft. With the exception of Bitter Lake, these values are all near the 10-percent exceedance probability (table 1). However, the average return periods are much higher than 10 years (204 years for Bitter Lake, 50 years for Enemy Swim Lake, 30 years for Pickerel Lake, and 154 years for Waubay Lake), and the average durations are longer than 1 year (20 years for Bitter Lake, 5 years for Enemy Swim Lake, 3 years for Pickerel Lake, and 15 years for Waubay Lake). Generally, the smaller upstream lakes, such as Pickerel and Enemy Swim Lakes, are more sensitive to short-term climatic fluctuations than the larger downstream lakes, such as Bitter and Waubay Lakes. Therefore, Enemy Swim and Pickerel Lakes generally reach levels similar to those in 1999 more often than Bitter and Waubay Lakes and stay at those levels for shorter time periods.

High lake-level frequency results for Waubay Lake with and without the farm crossings at the outlet between Rush Lake and Bitter Lake (table 1 of this report and table 14 of WRIR 99-4122) were compared. The exceedance levels corresponding to the 1-, 0.5-, and 0.2-percent exceedance probabilities are very 
Table 1. Probability of high lake levels using an unconditional frequency analysis for the Waubay Lakes Chain with the farm crossings removed at the outlet between Rush and Bitter Lakes

\begin{tabular}{|c|c|c|c|c|}
\hline Lake & $\begin{array}{l}\text { Exceedance } \\
\text { probability }^{1}\end{array}$ & $\begin{array}{c}\text { Exceedance level } \\
\text { (feet above } \\
\text { sea level) }\end{array}$ & $\begin{array}{l}\text { Average return } \\
\text { period }^{2} \\
\text { (years) }^{\text {years }}\end{array}$ & $\begin{array}{c}\text { Average } \\
\text { duration }^{3} \\
\text { (years) }\end{array}$ \\
\hline \multirow[t]{6}{*}{ Bitter } & $10(1$ in 10$)$ & $1,799.7$ & 204 & 20 \\
\hline & $4(1$ in 25$)$ & $1,805.0$ & 385 & 15 \\
\hline & $2(1$ in 50$)$ & $1,807.7$ & 769 & 15 \\
\hline & $1(1$ in 100$)$ & $1,810.0$ & 1,111 & 11 \\
\hline & $0.5(1$ in 200$)$ & $1,812.3$ & 1,667 & 8 \\
\hline & $0.2(1$ in 500$)$ & $1,814.0$ & 2,500 & 5 \\
\hline \multirow[t]{6}{*}{ Enemy Swim } & $10(1$ in 10$)$ & $1,854.0$ & 50 & 5 \\
\hline & $4(1$ in 25$)$ & $1,854.5$ & 71 & 3 \\
\hline & $2(1$ in 50$)$ & $1,854.9$ & 116 & 2 \\
\hline & $1(1$ in 100$)$ & $1,855.3$ & 185 & 2 \\
\hline & $0.5(1$ in 200$)$ & $1,855.7$ & 312 & 2 \\
\hline & $0.2(1$ in 500$)$ & $1,856.1$ & 500 & 1 \\
\hline \multirow[t]{6}{*}{ Pickerel } & $10(1$ in 10$)$ & $1,845.6$ & 30 & 3 \\
\hline & $4(1$ in 25$)$ & $1,845.9$ & 55 & 2 \\
\hline & $2(1$ in 50$)$ & $1,846.1$ & 83 & 2 \\
\hline & $1(1$ in 100$)$ & $1,846.4$ & 155 & 2 \\
\hline & $0.5(1$ in 200$)$ & $1,846.6$ & 244 & 1 \\
\hline & $0.2(1$ in 500$)$ & $1,846.7$ & 500 & 1 \\
\hline \multirow[t]{6}{*}{ Waubay } & $10(1$ in 10$)$ & $1,802.1$ & 154 & 15 \\
\hline & $4(1$ in 25$)$ & $1,806.3$ & 345 & 14 \\
\hline & $2(1$ in 50$)$ & $1,808.9$ & 625 & 13 \\
\hline & $1(1$ in 100$)$ & $1,811.0$ & 1,111 & 11 \\
\hline & $0.5(1$ in 200$)$ & 1.812 .3 & 1,667 & 8 \\
\hline & $0.2(1$ in 500$)$ & $1,814.1$ & 2.500 & 5 \\
\hline
\end{tabular}

${ }^{1}$ Percent of time the lake is above a given level.

${ }^{2}$ Average time between events when the lake is above a given level.

${ }^{3}$ Average time per event that the lake is above a given level.

similar (within $0.5 \mathrm{ft}$ ). Because the lake levels corresponding to these exceedance probabilities are substantially above elevation $1,807.5 \mathrm{ft}$, above which the Burlington Northern Railroad is the control (fig. 4), it was expected that the results wouldn't change greatly. However, the exceedance levels for the 10- and 4-percent exceedance probabilities decreased about $2 \mathrm{ft}$ without the farm crossings because more water is removed from Waubay Lake.

High lake-level frequency results for Bitter Lake with and without the farm crossings at the outlet between Rush Lake and Bitter Lake also were compared. The exceedance levels are very similar, with the exception of the 10-percent exceedance probability, which increased about $3 \mathrm{ft}$.
Even though the extreme high exceedance levels for both Bitter and Waubay Lakes have changed only slightly as the result of removing the two farm crossings, the average return periods and durations have increased significantly. For example, the average return period for the 1-percent exceedance probability for Waubay Lake increased from 769 years to 1,111 years, and the average duration increased from 8 years to 11 years. With the farm crossings removed, Waubay Lake reaches elevation 1,811.0 ft less often and stays there for longer periods than with the farm crossings in place.

The unconditional frequency analysis shows that the recent high levels of the Waubay Lakes Chain occur relatively infrequently. For example, the peak lake level of Waubay Lake was about an elevation of 
1,802.1 ft in 1998 and 1999; however, based on model simulations, Waubay Lake only reaches this elevation an average of once every 154 years and stays above this elevation an average of 15 years before subsiding. Enemy Swim Lake reaches an elevation of 1,856.1 ft, which was exceeded in 1997, an average of once every 500 years and stays above this elevation an average of 1 year before subsiding. Pickerel Lake reaches an elevation of $1,846.7 \mathrm{ft}$, which was equalled in 1997, an average of once every 500 years and stays above this elevation an average of 1 year before subsiding. The lake levels for the 1-percent exceedance probabilities in table 1 are about $18 \mathrm{ft}$ higher for Bitter Lake, $1.7 \mathrm{ft}$ higher for Enemy Swim Lake, $0.9 \mathrm{ft}$ higher for Pickerel Lake, and $7.3 \mathrm{ft}$ higher for Waubay Lake than the levels of those lakes that existed on September 13, 1999.

However, the average return periods are 1,111 years for Bitter Lake, 185 years for Enemy Swim Lake, 155 years for Pickerel Lake, and 1,111 years for Waubay Lake. For example, if in the next several years Bitter Lake continues to rise to an elevation of $1,810.0 \mathrm{ft}$, that would be an event that happens only once in an average of 1,111 years. If Bitter Lake does rise to an elevation of $1,810.0 \mathrm{ft}$, it could stay above that level for 11 years or longer before beginning to subside.
The average return periods for Enemy Swim and Pickerel Lakes for the 0.2-percent exceedance probabilities in table 1 are 500 years, indicating the extreme high lake levels of the smaller upstream lakes probably are caused by 1-year climatic extremes. However, the average return periods for Bitter and Waubay Lakes for the 0.2-percent exceedance probabilities are

2,500 years, indicating the extreme high lake levels of the larger downstream lakes are caused by extreme climatic conditions lasting several years.

Results from the unconditional frequency analysis for low lake levels for Bitter, Enemy Swim, Pickerel, and Waubay Lakes are given in table 2. The annual maximum lake levels generated using the stochastic time-series model were reduced by $2 \mathrm{ft}$ as described in WRIR 99-4122 because, in dry years, lake levels usually are about $2 \mathrm{ft}$ lower at the end of the summer than peak lake levels following spring runoff.

Low lake-level frequency results for Waubay and Bitter Lakes with and without the farm crossings at the outlet between Rush Lake and Bitter Lake were compared. The exceedance levels for Waubay and Bitter Lakes corresponding to all the exceedance probabilities are slightly higher $(0.1$ to $1.1 \mathrm{ft})$ without the farm crossings. Because the higher starting lake levels have no effect on the results from an unconditional frequency

Table 2. Probability of low lake levels using an unconditional frequency analysis for the Waubay Lakes Chain with the farm crossings removed at the outlet between Rush and Bitter Lakes

\begin{tabular}{|c|c|c|c|c|}
\hline Lake & $\begin{array}{c}\text { Non-exceedance } \\
\text { probability }^{\top}\end{array}$ & $\begin{array}{c}\text { Exceedance level } \\
\text { (feet above } \\
\text { sea level) }\end{array}$ & $\begin{array}{c}\text { Average return } \\
\text { period }^{2} \\
\text { (years) }\end{array}$ & $\begin{array}{c}\text { Average } \\
\text { duration } \\
\text { (years) }\end{array}$ \\
\hline \multirow[t]{3}{*}{ Bitter } & $10(1$ in 10$)$ & $1,778.1$ & 161 & 16 \\
\hline & $2(1$ in 50$)$ & $1,775.4$ & 435 & 9 \\
\hline & $1(1$ in 100$)$ & $1,774.3$ & 833 & 8 \\
\hline \multirow{2}{*}{ Enemy Swim } & $2(1$ in 50$)$ & $1,844.8$ & 294 & 6 \\
\hline & $1(1$ in 100$)$ & $1,844.1$ & 476 & 5 \\
\hline \multirow[t]{2}{*}{ Pickerel } & $10(1$ in 10$)$ & $1,842.9$ & 27 & 3 \\
\hline & $4(1$ in 25$)$ & $1,842.5$ & 40 & 2 \\
\hline \multirow{3}{*}{ Waubay } & $4(1$ in 25$)$ & $1,779.3$ & 256 & 10 \\
\hline & $2(1$ in 50$)$ & $1,778.1$ & 385 & 8 \\
\hline & $1(1$ in 100$)$ & $1,777.2$ & 625 & 6 \\
\hline
\end{tabular}

${ }^{1}$ Percent of time the lake is below a given level.

${ }^{2}$ Average time between events when the lake is below a given level.

${ }^{3}$ Average time per event that the lake is below a given level. 
analysis, the increase is attributed entirely to the removal of the farm crossings at the Rush-Bitter outlet. Bitter and Waubay Lakes have less variability when the lakes are above an elevation of $1,798.69 \mathrm{ft}$ because water can flow both ways between them. Therefore, both lakes likely will spend less time below elevation $1,798.69 \mathrm{ft}$ with the farm crossings removed, which results in the lower exceedance levels being increased for the corresponding exceedance probability.

The frequencies for extreme low lake levels are difficult to accurately determine because small changes in lake volumes result in large changes in lake levels. For example, as described in WRIR 99-4122, the volume of Bitter Lake at an elevation of $1,775 \mathrm{ft}$ differs only slightly from the volume at an elevation of $1,770 \mathrm{ft}$ (essentially dry). Likewise, the volume of Waubay Lake at an elevation of 1,780 ft differs only slightly from the volume at an elevation of $1,775 \mathrm{ft}$ (essentially dry). Therefore, the very small exceedance probabilities ( 0.5 and 0.2 percent) are not given in table 2. However, as indicated in table 2 and in WRIR 99-4122, the lake levels of Enemy Swim, Pickerel, and Waubay Lakes in the 1930's and 1940's were very low compared to the long-term lake levels. For example, for 12 years in the 1930's and early 1940's, Enemy
Swim Lake was below an elevation of $1,845 \mathrm{ft}$, which corresponds to a return period of about 300 years. Similarly, for 4 years in the 1930's, Pickerel Lake was below an elevation of $1,842 \mathrm{ft}$, which corresponds to a return period of about 125 years. For several years in the 1930's, Waubay Lake was below an elevation of $1,780 \mathrm{ft}$, which corresponds to a return period of about 256 years.

\section{Conditional Frequency Analysis}

A conditional frequency analysis was performed for the 10 major lakes of the Waubay Lakes Chain using 10,000 simulated 50-year lake-level traces, each starting on October 1, 1999, with the two farm crossings removed at the outlet between Rush Lake and Bitter Lake. The generated data can be used to estimate the probability of virtually any event that involves future lake levels.

The historic lake-level data for water years 1963-99 for Waubay Lake are shown in figure 6 along with five traces of generated hypothetical future lake levels. Also shown are the upper and lower 1-percent probability bounds for future (water years 2000-49)

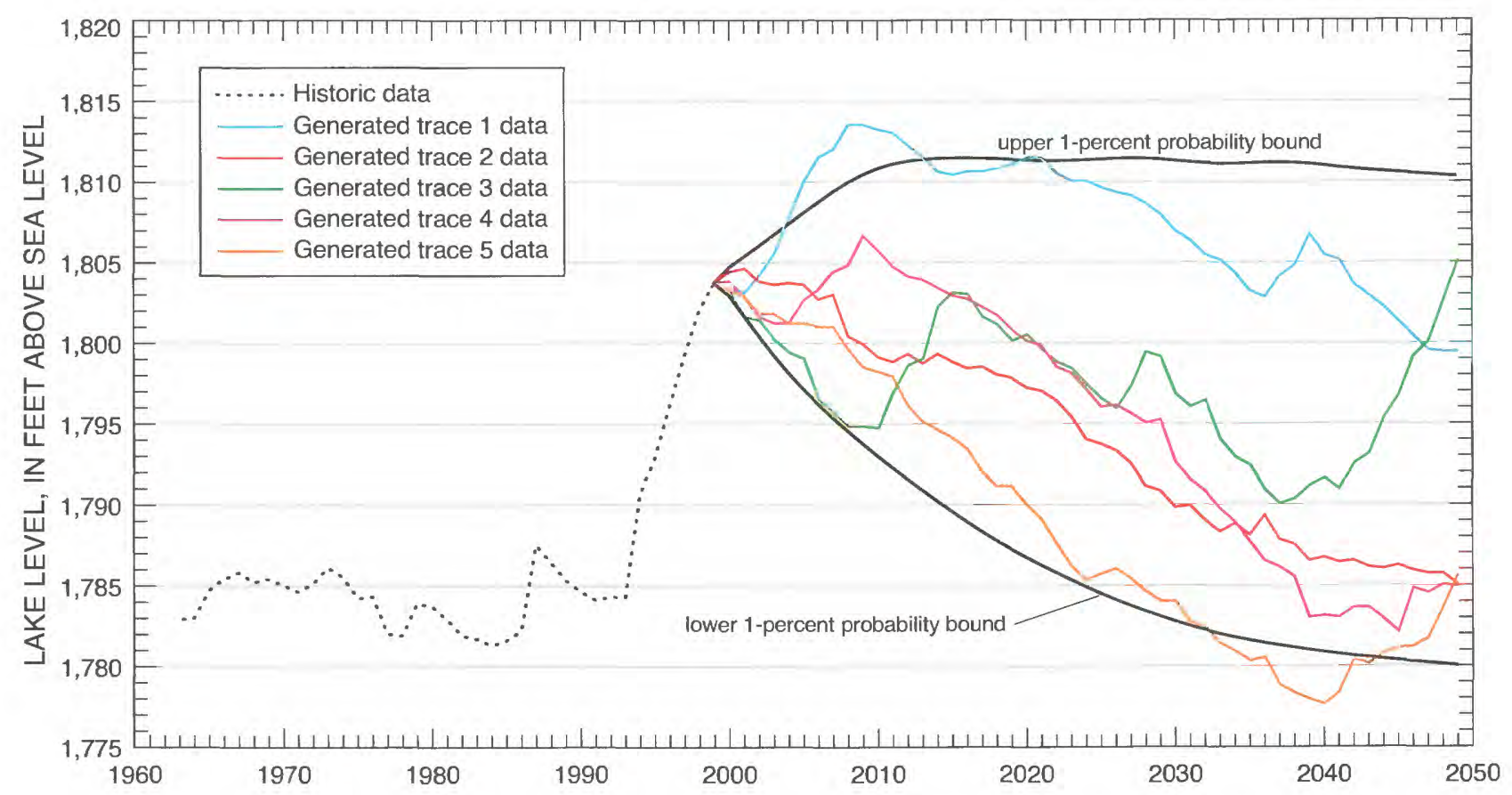

Figure 6. Historic (water years 1963-99) and generated (water years 2000-49) annual maximum lake levels for Waubay Lake with the farm crossings removed at the outlet between Rush and Bitter Lakes. 
lake levels. The frequency results for Waubay Lake (fig. 6) indicate the upper 1-percent probability bound rises quickly to a constant level at an elevation of $1,811 \mathrm{ft}$ at the end of water year 2011 , which corresponds to the unconditional 1-percent exceedance level discussed previously (table 1). Therefore, the chance that Waubay Lake will continue to rise to the spill elevation with the Big Sioux River (elevation 1,811.1 ft) within the next 10 to 15 years is greater than 1 percent. The lower 1-percent probability bound falls slowly during the next 50 years. It reaches an elevation of $1,785 \mathrm{ft}$ in 2024 , indicating that there is about a 1-percent chance Waubay Lake will return to levels comparable to historic 1960-92 levels (about elevation $1,785.0 \mathrm{ft}$ ) in the next 25 years. Also, Waubay Lake is unlikely to return to levels comparable to those during the extreme drought of the 1930's (about elevation $1,775 \mathrm{ft}$ ) for much longer than 50 years. Table 3 shows the probability of Waubay Lake exceeding lake levels between elevations 1,785 to $1,815 \mathrm{ft}$ during the next 50 years.

A comparison was done between the frequency results for Waubay Lake with (modified outlet) and without (unmodified outlet) the farm crossings at the outlet between Rush and Bitter Lakes. The upper 0.2and 1-percent probability bounds with the modified outlet rise slightly slower than the upper 0.2- and 1-percent probability bounds with the unmodified outlet. However, by the end of water year 2010, the bounds are nearly identical because, at high lake levels, Waubay Lake will be nearly the same level as Bitter Lake, and the farm crossings will have little impact on the lake levels in the Waubay Lakes Chain. The 0.2and 1-percent probability bounds with the modified outlet do not rise as quickly as the unmodified outlet bounds because more water is being moved from Waubay Lake to Bitter Lake. The lower 0.2- and 1-percent probability bounds with the modified outlet are very close to the lower 0.2 - and 1-percent probability bounds with the farm crossings in place at the outlet. The upper and lower 10-percent probability bounds are affected the most by the modified outlet. The upper 10-percent probability bound is about $2 \mathrm{ft}$ below the upper 10-percent probability bound with the unmodified outlet, and the lower 10-percent probability bound is about $1 \mathrm{ft}$ below the upper 10-percent probability bound with the unmodified outlet. The removal of the farm crossings results in less water in Waubay Lake and causes the lower probability bounds.
The 0.2-, 1-, and 10-percent upper and lower probability bounds for the 10 major lakes of the Waubay Lakes Chain are shown in figures 7 through 16. The 1-percent probability bounds shown in figure 6 for Waubay Lake are the same as those shown in figure 16.

The frequency results for Bitter Lake (fig. 7) indicate the upper 10-percent probability bound increases about $10 \mathrm{ft}$ during water years 1999-2010 and then slowly decreases, and the upper 1-percent probability bound increases about $19 \mathrm{ft}$ during water years 1999-2015 and then becomes nearly constant at about elevation 1,810 ft. The chance that the level of Bitter Lake will continue to rise to the spill elevation with the Big Sioux River within the next 15 to 20 years is greater than 1 percent. Conversely, the lower 10-percent probability bound decreases about $9 \mathrm{ft}$ during water years 1999-2025 and then slowly decreases to an elevation of about $1,780.5 \mathrm{ft}$ by the end of water year 2049. Furthermore, the lower 1-percent probability bound decreases about $11 \mathrm{ft}$ during water years 1999-2025 and then slowly decreases to an elevation of about $1,777.5 \mathrm{ft}$ by the end of water year 2049 . Therefore, there is about a 1-percent chance that Bitter Lake will return to levels comparable to historic 1960-92 levels (about elevation 1,775 ft) in the next 50 years.

A comparison was done between the frequency results for Bitter Lake with and without the farm crossings at the outlet between Rush and Bitter Lakes. The upper 0.2-percent probability bounds are nearly identical for both results. The upper 1-percent probability bound rises slightly quicker than the upper 1-percent probability bound with the unmodified outlet, but by the end of water year 2010 , the bounds are nearly identical. This is because, at high lake levels, Bitter Lake will be at nearly the same lake level as the other lakes in the Waubay Lakes Chain (with the exception of Pickerel and Enemy Swim Lakes) and the farm crossings will have little effect on the lake levels. Until about the end of water year 2010, the lower 0.2 - and 1-percent probability bounds initially are about 4 to $5 \mathrm{ft}$ above the lower 0.2 - and 1-percent probability bounds with the unmodified outlet. From water years 2011-48, this difference slowly decreases until, by the end of water year 2048, the difference in the probability bounds is less than $1 \mathrm{ft}$. This is caused by the higher initial lake level in Bitter Lake plus the inflow from Rush Lake to Bitter Lake, but as the years pass and Bitter Lake separates from the other lakes of the 
Table 3. Probability of Waubay Lake exceeding selected lake levels in each of the next 50 years, using October 1, 1999, starting lake levels and with the farm crossings removed at the outlet between Rush and Bitter Lakes

\begin{tabular}{|c|c|c|c|c|c|c|c|}
\hline \multirow{2}{*}{ Water year } & \multicolumn{7}{|c|}{ Exceedance probability (in percent) for lake level (in feet above sea level) } \\
\hline & 1,785 & 1,790 & 1,795 & 1,800 & 1,805 & 1,810 & 1,815 \\
\hline 2000 & 100 & 100 & 100 & 100 & 0 & 0 & 0 \\
\hline 2001 & 100 & 100 & 100 & 100 & 2.5 & 0 & 0 \\
\hline 2002 & 100 & 100 & 100 & 99 & 2.5 & 0 & 0 \\
\hline 2003 & 100 & 100 & 100 & 85 & 3.2 & .02 & 0 \\
\hline 2004 & 100 & 100 & 100 & 62 & 4.6 & .1 & 0 \\
\hline 2005 & 100 & 100 & 100 & 46 & 5.4 & 3 & 0 \\
\hline 2006 & 100 & 100 & 100 & 38 & 6.0 & .6 & .01 \\
\hline 2007 & 100 & 100 & 99 & 34 & 6.4 & .8 & .03 \\
\hline 2008 & 100 & 100 & 97 & 31 & 6.6 & 1.1 & .04 \\
\hline 2009 & 100 & 100 & 94 & 29 & 6.8 & 1.2 & .04 \\
\hline 2010 & 100 & 100 & 88 & 28 & 7.0 & 1.5 & .03 \\
\hline 2011 & 100 & 100 & 82 & 27 & 7.1 & 1.6 & .02 \\
\hline 2012 & 100 & 100 & 76 & 26 & 6.9 & 1.7 & .01 \\
\hline 2013 & 100 & 100 & 71 & 24 & 7.0 & 1.7 & .02 \\
\hline 2014 & 100 & 99 & 67 & 24 & 7.1 & 1.7 & .02 \\
\hline 2015 & 100 & 98 & 63 & 23 & 7.0 & 1.7 & .04 \\
\hline 2016 & 100 & 97 & 60 & 22 & 6.8 & 1.7 & .03 \\
\hline 2017 & 100 & 95 & 58 & 22 & 6.8 & 1.7 & .05 \\
\hline 2018 & 100 & 92 & 56 & 22 & 6.7 & 1.7 & .03 \\
\hline 2019 & 100 & 91 & 54 & 21 & 6.6 & 1.7 & .03 \\
\hline 2020 & 100 & 88 & 53 & 21 & 6.5 & 1.6 & .03 \\
\hline 2021 & 100 & 86 & 51 & 20 & 6.2 & 1.4 & .02 \\
\hline 2022 & 100 & 85 & 50 & 20 & 6.1 & 1.6 & .04 \\
\hline 2023 & 99 & 83 & 49 & 20 & 6.1 & 1.6 & .01 \\
\hline 2024 & 99 & 81 & 48 & 20 & 5.8 & 1.5 & .02 \\
\hline 2025 & 98 & 79 & 47 & 19 & 5.7 & 1.6 & .04 \\
\hline 2026 & 98 & 78 & 45 & 19 & 5.6 & 1.5 & .05 \\
\hline 2027 & 97 & 76 & 45 & 18 & 5.4 & 1.5 & .01 \\
\hline 2028 & 97 & 75 & 45 & 18 & 5.4 & 1.5 & .03 \\
\hline 2029 & 96 & 74 & 44 & 18 & 5.2 & 1.4 & .04 \\
\hline 2030 & 95 & 73 & 44 & 18 & 5.0 & 1.5 & .04 \\
\hline 2031 & 95 & 72 & 43 & 18 & 5.0 & 1.5 & .03 \\
\hline 2032 & 94 & 71 & 42 & 17 & 4.8 & 1.4 & .03 \\
\hline 2033 & 93 & 70 & 42 & 17 & 4.9 & 1.4 & .05 \\
\hline 2034 & 93 & 69 & 41 & 17 & 5.0 & 1.3 & .04 \\
\hline 2035 & 92 & 69 & 40 & 16 & 4.9 & 1.3 & .02 \\
\hline 2036 & 92 & 68 & 40 & 16 & 4.8 & 1.4 & 0.04 \\
\hline 2037 & 91 & 67 & 40 & 16 & 4.7 & 1.4 & .03 \\
\hline 2038 & 91 & 66 & 40 & 16 & 4.7 & 1.3 & .09 \\
\hline 2039 & 90 & 66 & 40 & 16 & 4.6 & 1.4 & .05 \\
\hline 2040 & 90 & 65 & 39 & 16 & 4.7 & 1.4 & .06 \\
\hline 2041 & 89 & 65 & 39 & 15 & 4.7 & 1.3 & .07 \\
\hline 2042 & 88 & 64 & 38 & 15 & 4.8 & 1.2 & .07 \\
\hline 2043 & 88 & 63 & 38 & 15 & 4.5 & 1.2 & .07 \\
\hline 2044 & 88 & 63 & 38 & 15 & 4.4 & 1.1 & .03 \\
\hline 2045 & 87 & 63 & 37 & 15 & 4.4 & 1.1 & .01 \\
\hline 2046 & 87 & 62 & 37 & 15 & 4.2 & 1.2 & .03 \\
\hline 2047 & 87 & 62 & 37 & 15 & 4.1 & 1.1 & .04 \\
\hline 2048 & 86 & 62 & 37 & 15 & 4.1 & 1.1 & .01 \\
\hline 2049 & 86 & 62 & 37 & 15 & 4.1 & 1.2 & .02 \\
\hline
\end{tabular}




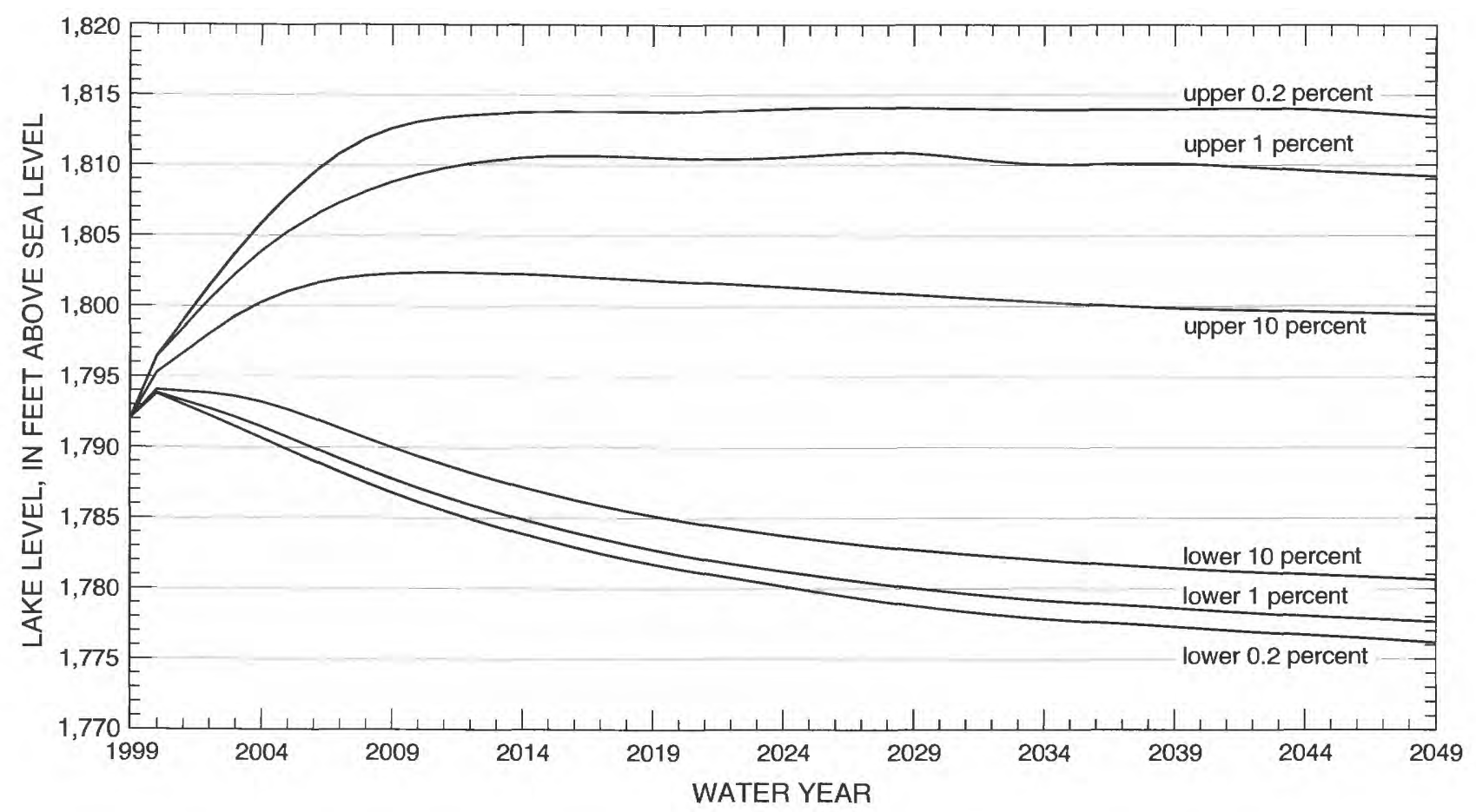

Figure 7. Upper and lower probability bounds for Bitter Lake computed from 10,000 50-year traces from the water mass-balance model, with each trace starting October 1, 1999, and with the farm crossings removed at the outlet between Rush and Bitter Lakes.

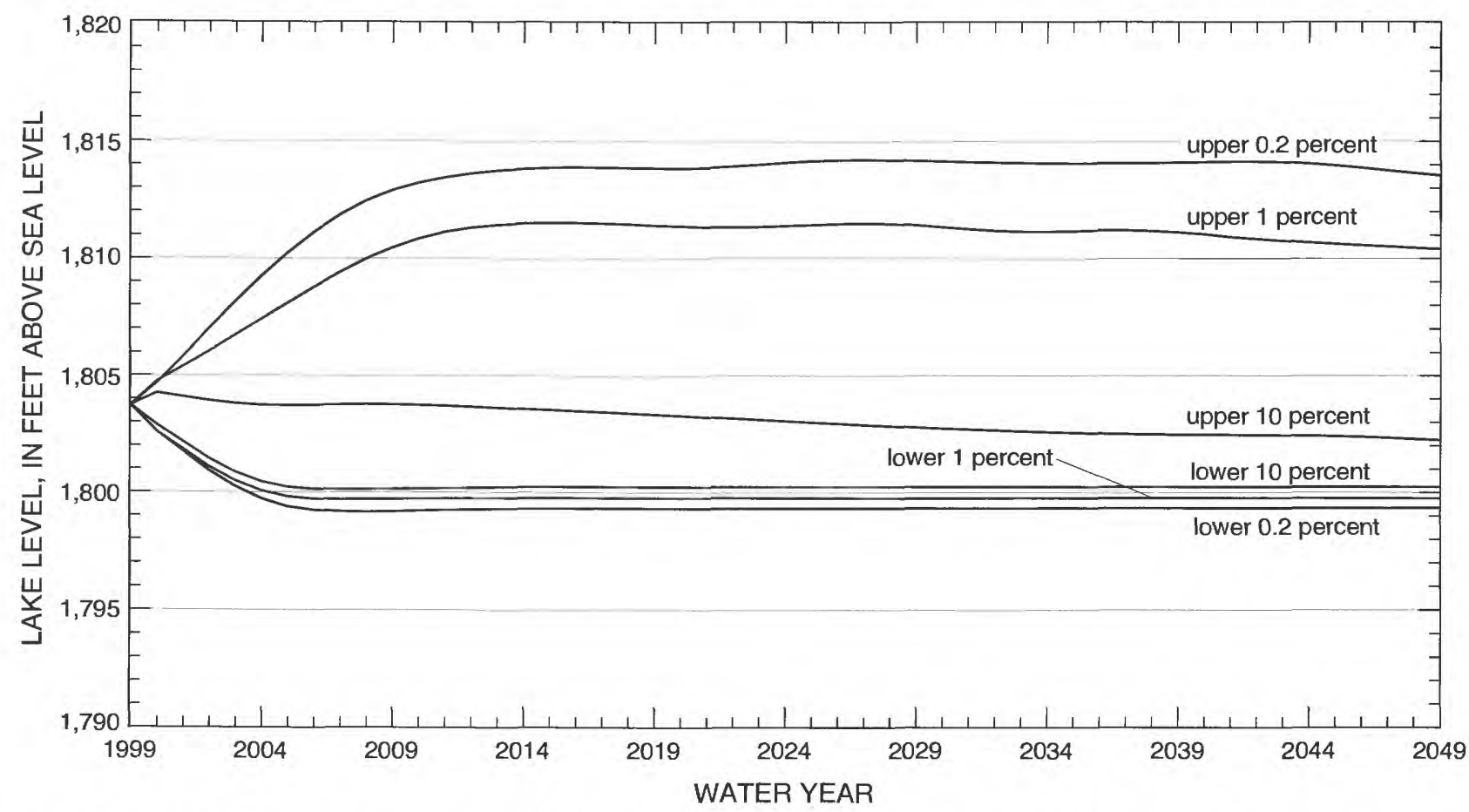

Figure 8. Upper and lower probability bounds for Blue Dog Lake computed from 10,000 50-year traces from the water mass-balance model, with each trace starting October 1,1999, and with the farm crossings removed at the outlet between Rush and Bitter Lakes. 


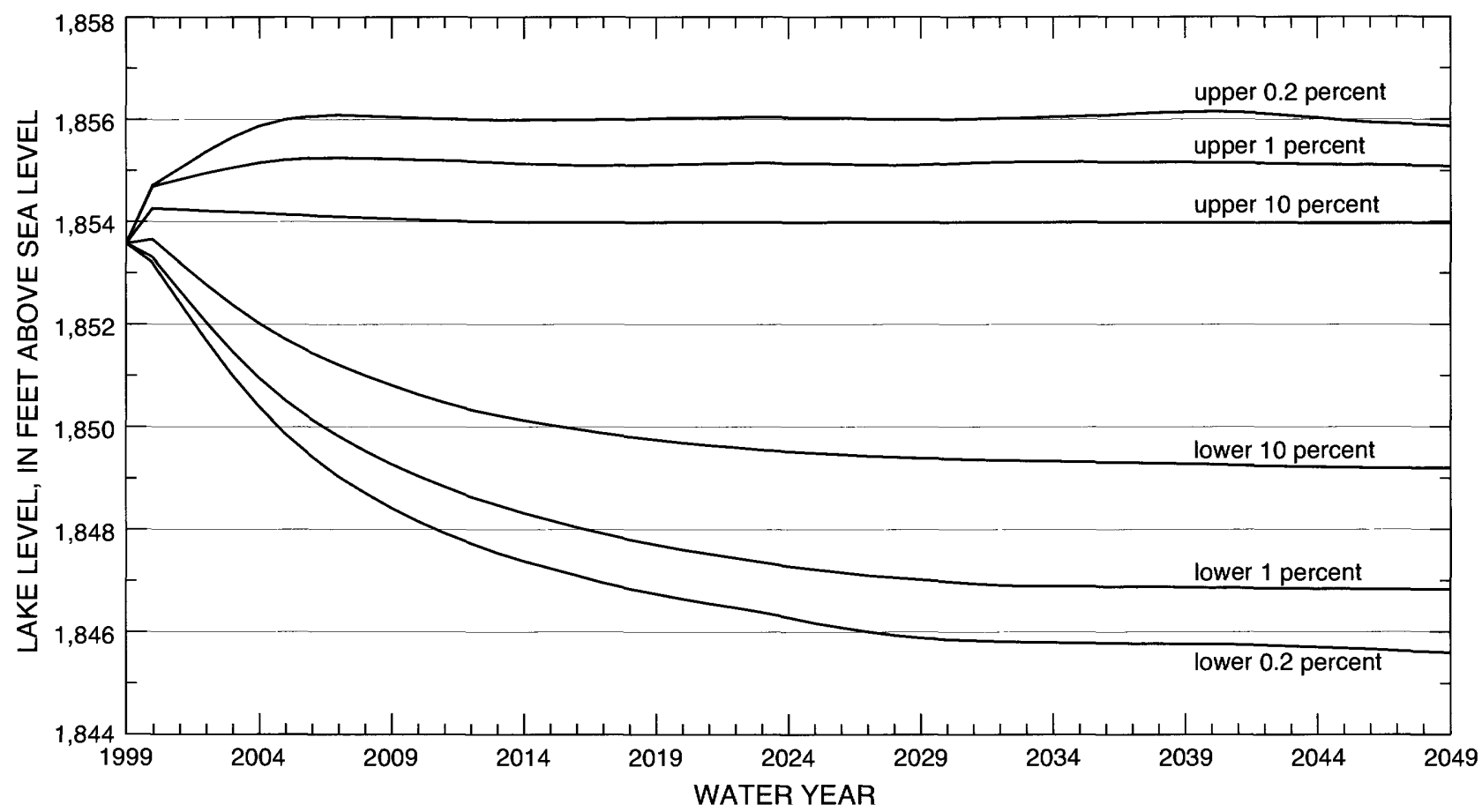

Figure 9. Upper and lower probability bounds for Enemy Swim Lake computed from 10,000 50-year traces from the water mass-balance model, with each trace starting October 1, 1999, and with the farm crossings removed at the outlet between Rush and Bitter Lakes.

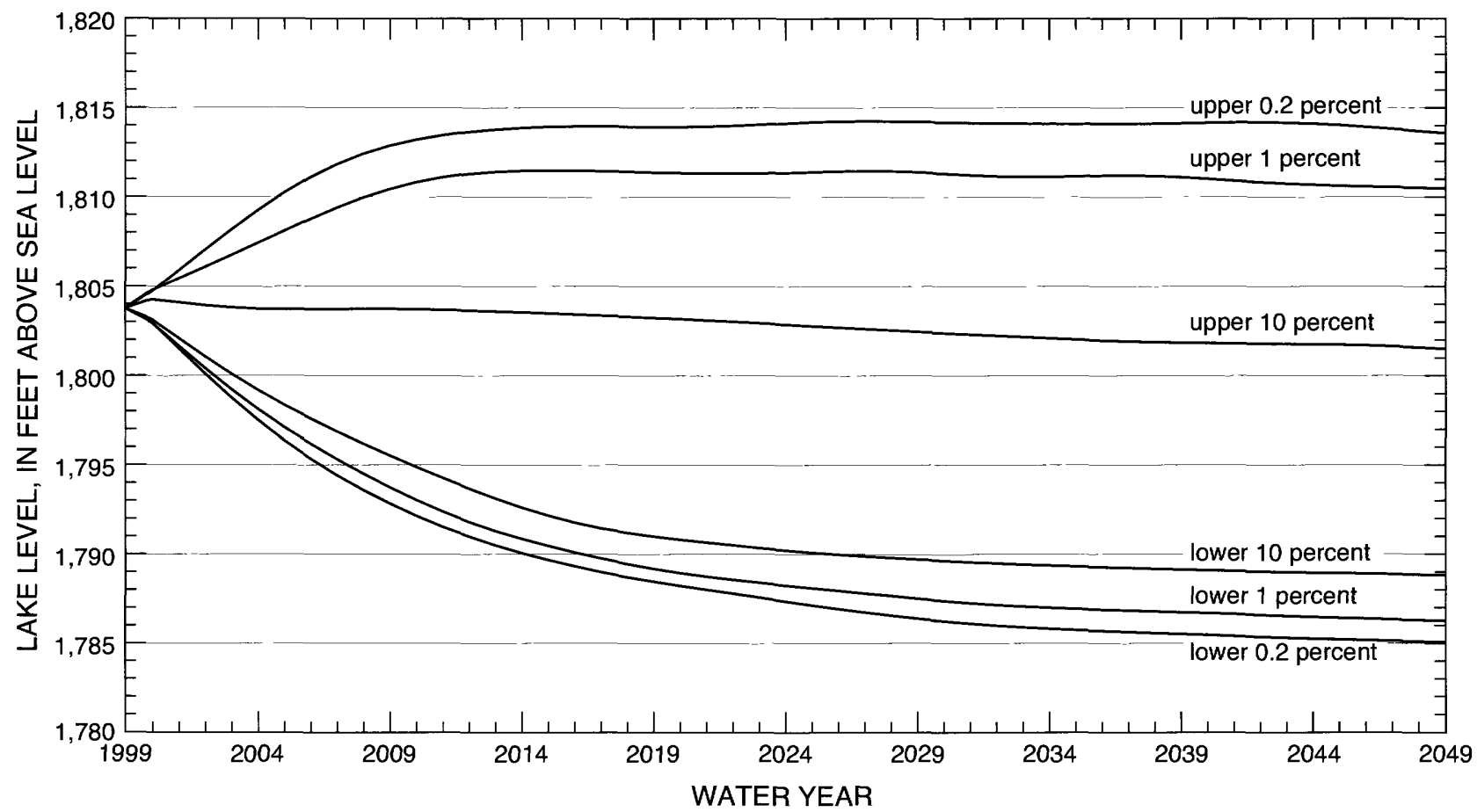

Figure 10. Upper and lower probability bounds for Hillebrands Lake computed from 10,000 50-year traces from the water mass-balance model, with each trace starting October 1, 1999, and with the farm crossings removed at the outlet between Rush and Bitter Lakes. 


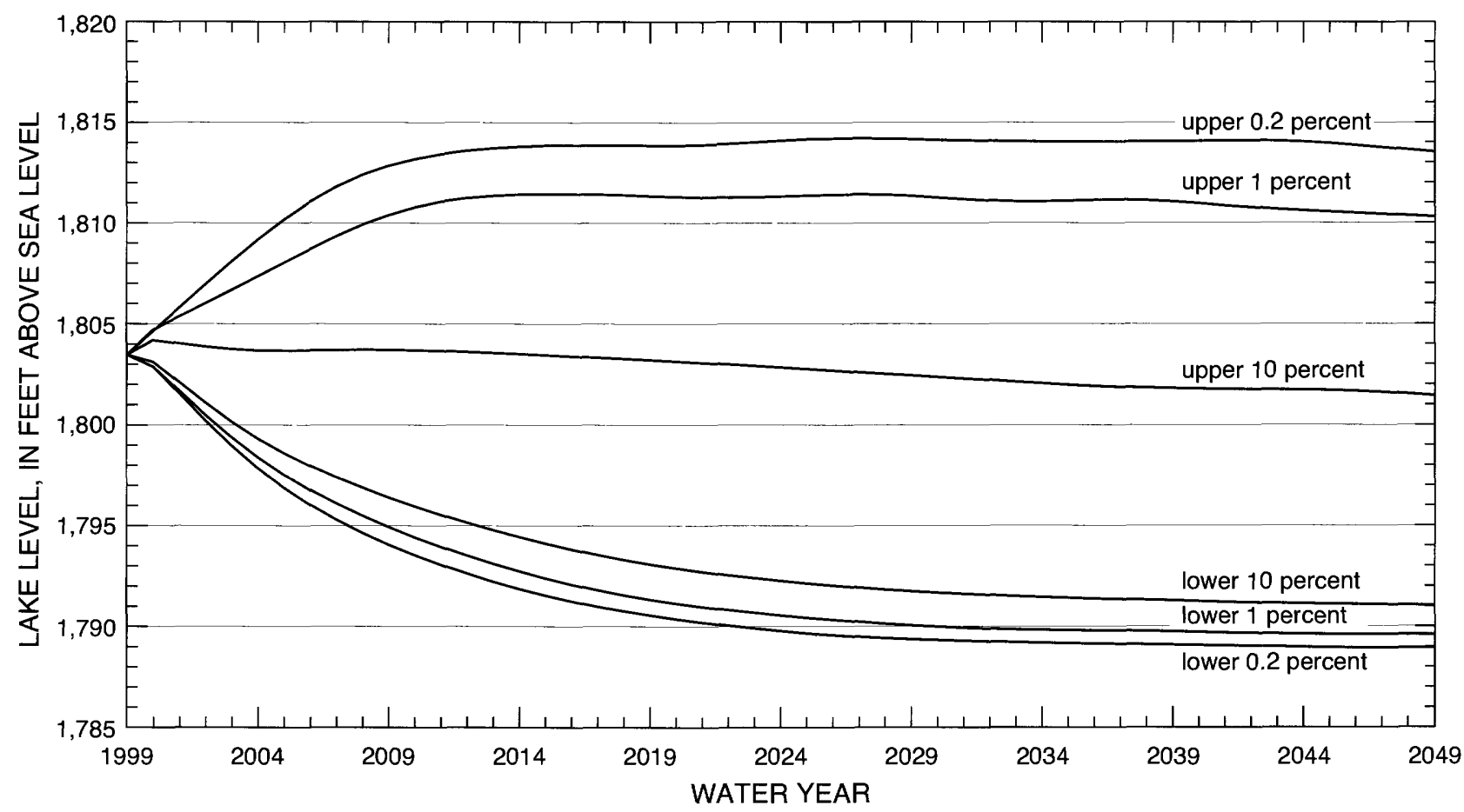

Figure 11. Upper and lower probability bounds for Minnewasta Lake computed from 10,000 50-year traces from the water mass-balance model, with each trace starting October 1,1999, and with the farm crossings removed at the outlet between Rush and Bitter Lakes.

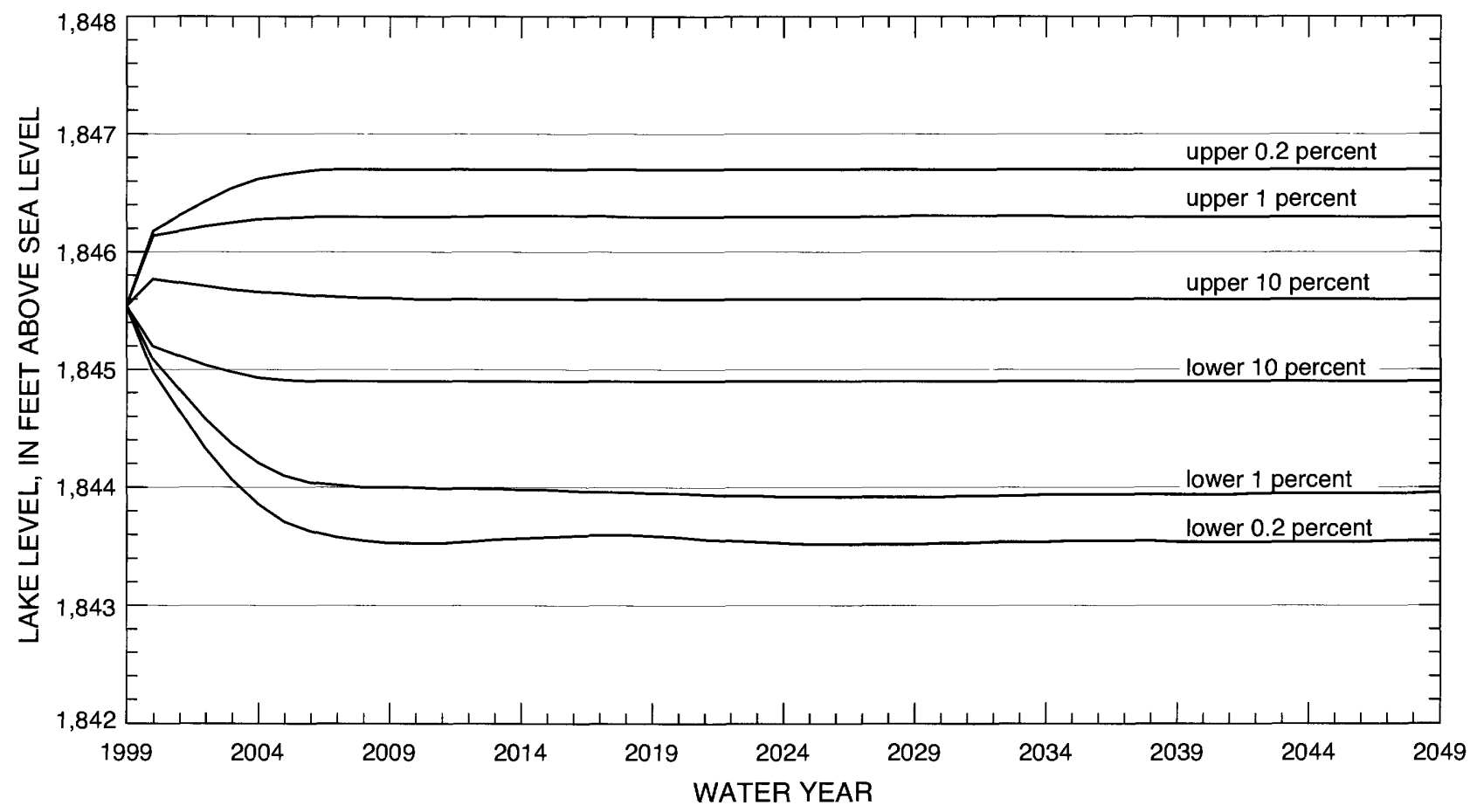

Figure 12. Upper and lower probability bounds for Pickerel Lake computed from 10,000 50-year traces from the water mass-balance model, with each trace starting October 1, 1999, and with the farm crossings removed at the outlet between Rush and Bitter Lakes. 


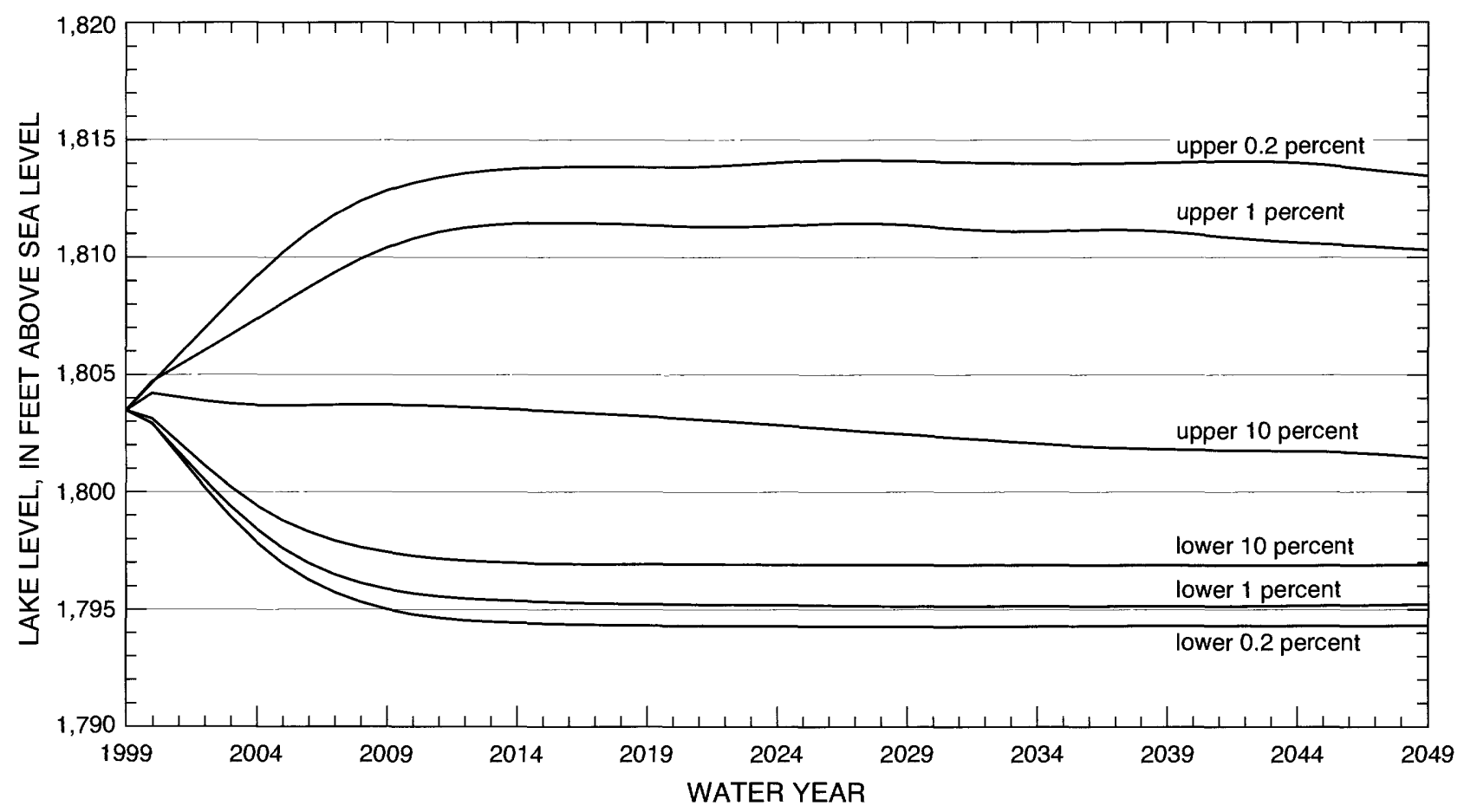

Figure 13. Upper and lower probability bounds for Rush Lake computed from 10,000 50-year traces from the water mass-balance model, with each trace starting October 1, 1999, and with the farm crossings removed at the outlet between Rush and Bitter Lakes.

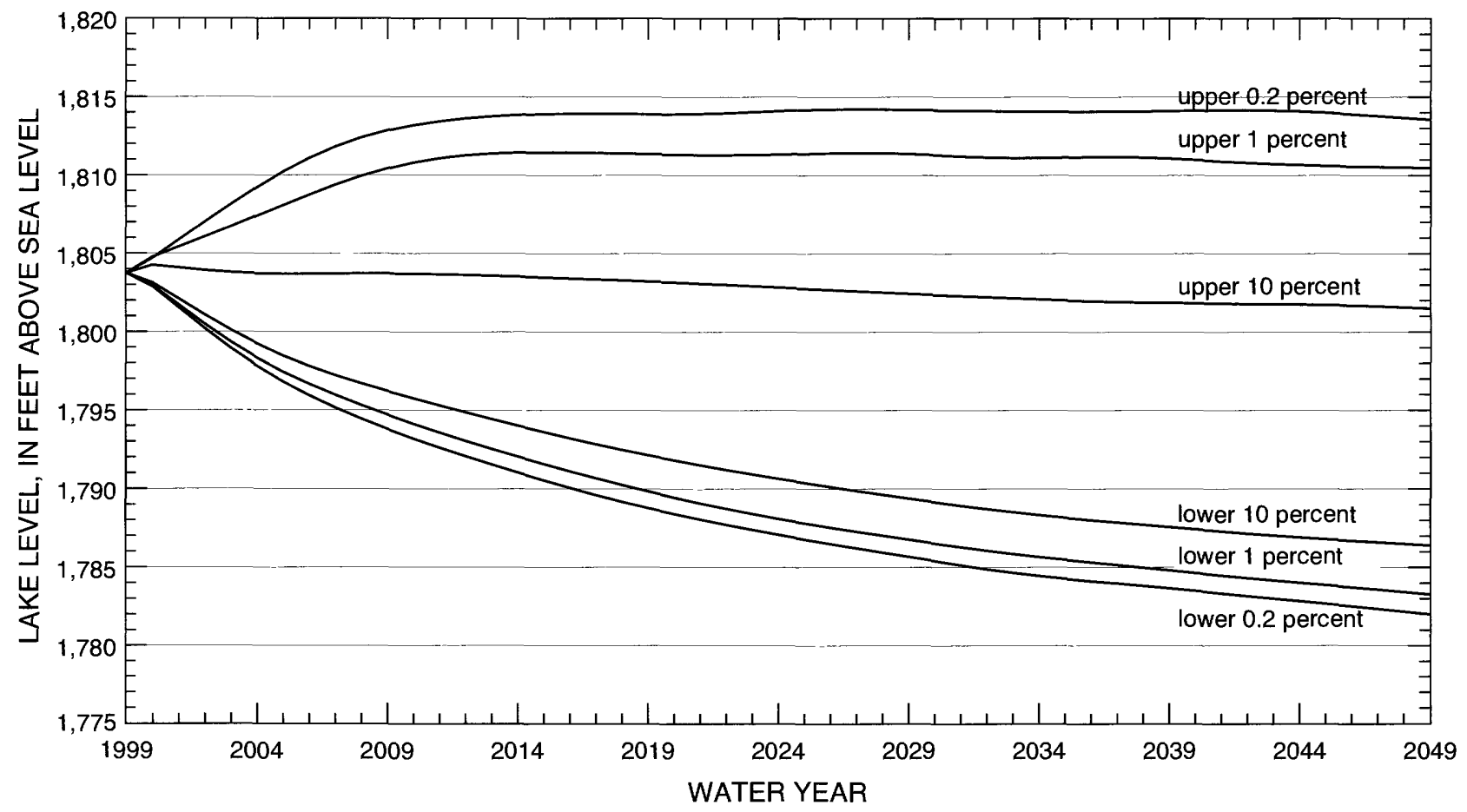

Figure 14. Upper and lower probability bounds for Spring Lake computed from 10,000 50-year traces from the water mass-balance model, with each trace starting October 1, 1999, and with the farm crossings removed at the outlet between Rush and Bitter Lakes. 


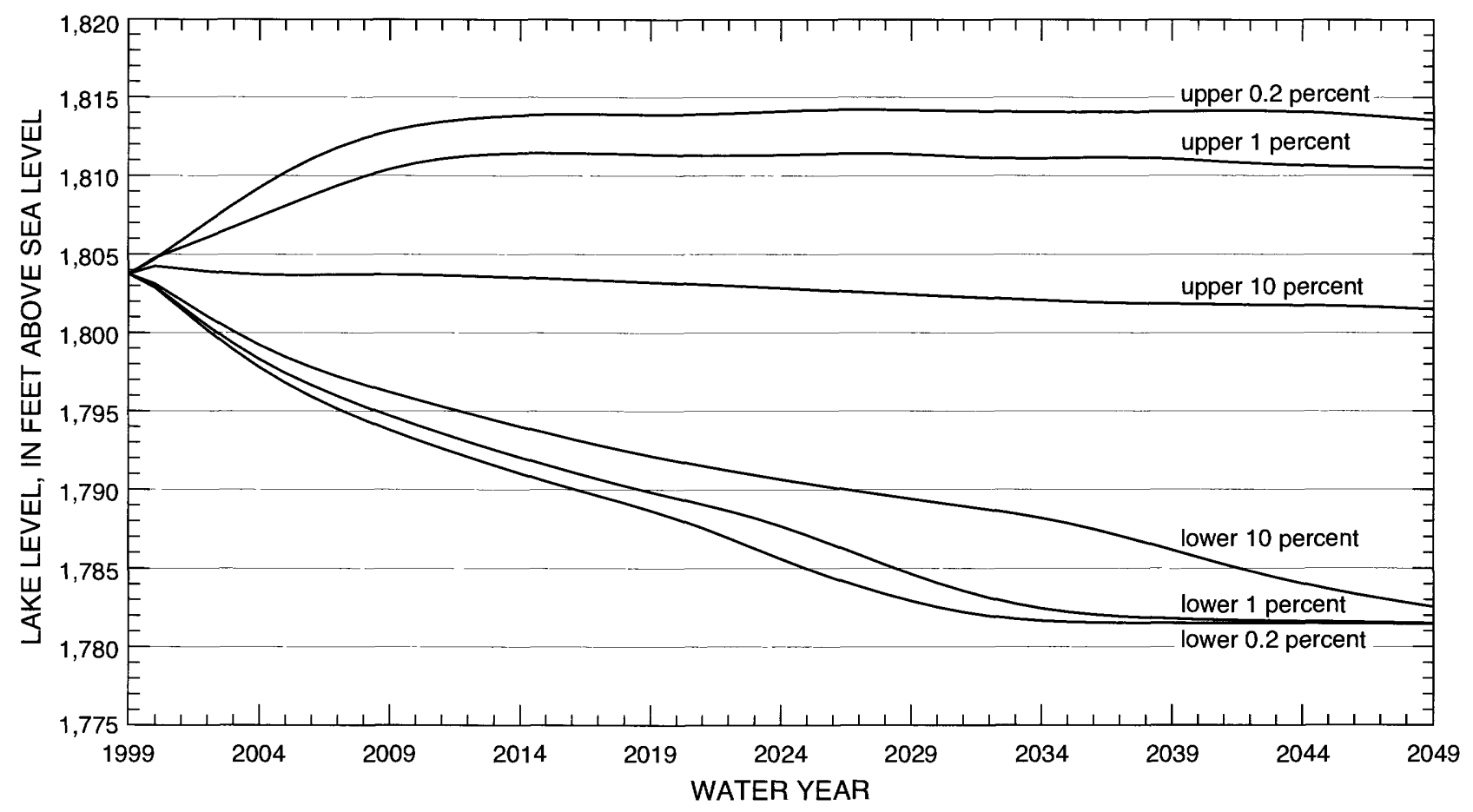

Figure 15. Upper and lower probability bounds for Swan Pond computed from 10,000 50-year traces from the water mass-balance model, with each trace starting October 1, 1999, and with the farm crossings removed at the outlet between Rush and Bitter Lakes.

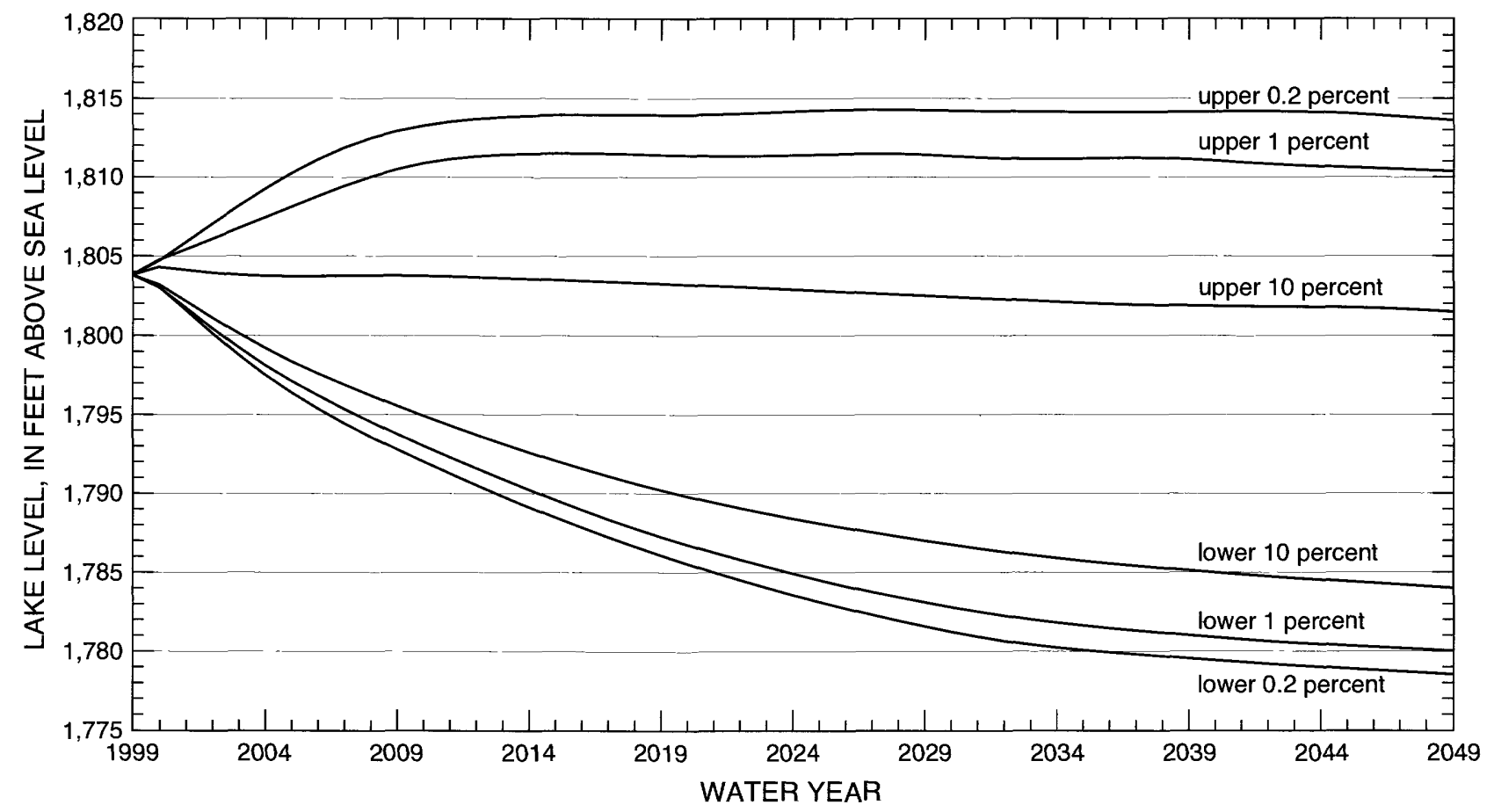

Figure 16. Upper and lower probability bounds for Waubay Lake computed from 10,000 50-year traces from the water mass-balance model, with each trace starting October 1, 1999, and with the farm crossings removed at the outlet between Rush and Bitter Lakes. 
Waubay Lakes Chain, the effect of the farm crossings is diminished. The upper 10-percent probability bound is affected the most by the modified outlet. The removal of the farm crossings causes the upper 10-percent bound to rise much quicker and stay about $3 \mathrm{ft}$ above the upper 10-percent bound with the unmodified outlet for water years 1999-2048. The removal of the farm crossings causes more inflow to Bitter Lake from the other lakes of the Waubay Lakes Chain. The lower 10-percent bounds are affected much less and actually converge within $1 \mathrm{ft}$ at the end of water year 2048 .

The frequency results for Hillebrands Lake (fig. 10), Rush Lake (fig. 13), Spring Lake (fig. 14), Swan Pond (fig. 15), and Waubay Lake (fig. 16) indicate the upper 10-, 1-, and 0.2-percent probability bounds are about the same for all five lakes because the lakes are joined with Waubay Lake above an elevation of 1,797.6 ft. The frequency results for Blue Dog (fig. 8) and Minnewasta (fig. 11) Lakes also are similar to Waubay Lake because they are joined with Waubay Lake above an elevation of $1,800.2 \mathrm{ft}$. The upper 10 -percent probability bounds are constant until the end of water year 2010 then slowly decrease, and the upper 1-percent probability bounds increase about $8 \mathrm{ft}$ from the current level and reach an elevation of $1,811.5 \mathrm{ft}$ in water year 2015. These increases are smaller than the increases for Bitter Lake, partly because of water spilling from Rush Lake to Bitter Lake as the level of Rush Lake continues to increase. The upper 0.2-percent probability bounds for Bitter and Rush Lakes become about equal after year 2010 because enough water spills from the upstream lakes to fill Bitter Lake to the extreme high levels of Rush Lake. As with Waubay Lake, the conditional frequency analysis for Blue Dog Lake, Hillebrands Lake, Minnewasta Lake, Rush Lake, Spring Lake, and Swan Pond indicates that the chance the lakes will continue to rise to the spill elevation with the Big Sioux River within the next 10 to 15 years is greater than 1 percent.

The lower probability bounds for Hillebrands Lake, Minnewasta Lake, Spring Lake, Swan Pond, and Waubay Lake are similar, with each bound decreasing slowly during the entire 50-year simulation period. There is about a 1-percent chance that Hillebrands Lake, Spring Lake, Swan Pond, and Waubay Lake will decrease to historic 1960-92 levels in the next 25 years. However, the lower probability bounds for Blue Dog and Rush Lakes become nearly constant by year 2010 and beyond and, indicate that there is about a 10-percent chance Blue Dog and Rush Lakes could return to historic 1960-92 levels within 10 years. Blue Dog and Rush Lakes are much shallower than the other lakes, and both lakes spill regularly under normal climatic conditions. Therefore, levels of both lakes respond quickly to short-term climatic reversals.

The frequency results for Enemy Swim Lake (fig. 9) and Pickerel Lake (fig. 12) are totally unaffected by the removal of the farm crossings at the outlet between Rush and Bitter Lakes. Because Enemy Swim and Pickerel Lakes spill frequently and never join with the downstream lakes, the upper probability bounds for both lakes remain nearly constant for the entire simulation period. Therefore, Enemy Swim and Pickerel Lakes are unlikely to increase significantly over current levels, and both lakes could return to historic 1960-92 levels much sooner than the other lakes under a reversal of the current wet conditions. The lower probability bounds for Enemy Swim Lake decrease more slowly than those for Pickerel Lake. The bounds for Enemy Swim Lake become nearly constant in about year 2030, and the bounds for Pickerel Lake become nearly constant in about 2005.

The lake extents for the Waubay Lakes Chain corresponding to the $0.2-, 1-, 2-, 4-, 10-$, and 50-percent probabilities (conditional analysis) based on October 1, 1999, starting lake levels and with the farm crossings removed at the outlet between Rush and Bitter Lakes are shown on plate 1. Lake extents shown on plate 1 do not reflect areas that may be protected by dikes constructed near the city of Waubay during 1998. Exceedance elevations for different probabilities may be similar and, therefore, their respective inundated areas may be nearly indistinguishable at the scale shown $(1: 100,000)$.

\section{Climatic Scenarios}

The climatic scenarios analysis summarized in WRIR 99-4122 also was revised to account for the removal of the farm crossings at the outlet between Rush and Bitter Lakes. The beginning lake levels used in the revised climatic scenarios also were changed to represent October 1, 1999, starting conditions.

As previously described in WRIR 99-4122, each of five 8-year descriptive net lake evaporation classifications was paired to form 25 possible 16-year sequences. Of these 25 , five were selected to represent the range of resulting lake levels. The five scenarios include wet-wet, wet-dry, average-average, dry-wet, and dry-dry net lake evaporation. 
The climatic-scenario revised results for Bitter (fig. 17) and Waubay (fig. 18) Lakes due to the changes in the outlet elevation between Rush and Bitter Lakes were used to represent all the lakes of the Waubay Lakes Chain. Bitter Lake is most affected by the modified outlet because, with the farm crossings removed, it receives more water from the upstream lakes. Waubay Lake is representative of the upstream lakes when they are connected at high levels. Figures 17 and 18 correspond to figures 41 and 42 in WRIR 99-4122. Both lakes have higher lake levels at the beginning of the scenarios than in WRIR 99-4122, with Bitter Lake being $1.1 \mathrm{ft}$ higher, and Waubay Lake being $1.7 \mathrm{ft}$ higher. Because the outlet between Rush and Bitter Lakes was at an elevation of 1,803.6 ft, and the culvert invert now joining the two lakes is at an elevation of $1,798.69 \mathrm{ft}$, the lakes begin to interact with one another at an elevation $4.91 \mathrm{ft}$ lower than previously. Thus, Rush Lake will begin to spill to Bitter Lake at a lower elevation, causing earlier rises in Bitter Lake and delayed rises in Waubay Lake (and the other lakes connected to it) compared to the previous climatic scenarios with the farm crossings in place. For both lakes, lake levels at the end of the wet-wet and wet-dry scenarios are very similar (within $1 \mathrm{ft}$ ) to the levels presented in WRIR 99-4122. With the farm crossings removed, Bitter Lake rises $21.4 \mathrm{ft}$ and Waubay Lake rises $9.8 \mathrm{ft}$ by the end of a 16-year wet-wet scenario. Bitter and Waubay Lakes, after 16 years, would combine into one lake that has an elevation of about $1,813.5 \mathrm{ft}$, which is $2.4 \mathrm{ft}$ above the level at which Bitter Lake would begin to flow out of the closed basin. Even though both lakes started the simulation with higher lake levels than in WRIR 99-4122, they do not end the simulation with appreciably higher levels because the outlet to the Big Sioux River effectively sets the upper limit of lake levels. The maximum annual water-level rise in Bitter Lake would be $4.0 \mathrm{ft}$, and the maximum annual water-level rise in Waubay Lake would be $1.8 \mathrm{ft}$, occurring in year 2000 and 2004, respectively (corresponding to 1991 and 1995 climatic conditions). In the wet-dry scenario, Bitter Lake rises $9.5 \mathrm{ft}$ and Waubay Lake declines $1.9 \mathrm{ft}$ by the end of the 16-year period. In the dry-wet and average-average scenarios with the farm crossings removed, Bitter Lake rises $11.2 \mathrm{ft}$ and $6.4 \mathrm{ft}$, respectively, while Waubay Lake rises $0.90 \mathrm{ft}$ and declines $4.6 \mathrm{ft}$, respectively, by the end of the 16-year period. In the dry-dry scenario with the farm crossings removed, Bitter Lake declines
$3.9 \mathrm{ft}$ and Waubay Lake declines $14.7 \mathrm{ft}$ by the end of the 16-year period. The maximum annual water-level decline in Bitter and Waubay Lakes would be $2.6 \mathrm{ft}$ occurring in year 2007 (corresponding to 1976 climatic conditions).

Differences in the ending lake levels for the three scenarios that start with either average or dry conditions are markedly different than the scenario results with the farm crossings in place. Bitter Lake is higher and Waubay Lake is lower at the end of these three scenarios. Under the average-average scenario, Bitter Lake ends $5.6 \mathrm{ft}$ higher and Waubay Lake ends $3.2 \mathrm{ft}$ lower than the corresponding scenarios presented in WRIR 99-4122. Under the dry-wet scenario, Bitter Lake ends $3.5 \mathrm{ft}$ higher and Waubay Lake ends $2.2 \mathrm{ft}$ lower, while under the dry-dry scenario, Bitter Lake ends $3.8 \mathrm{ft}$ higher and Waubay Lake ends $2.6 \mathrm{ft}$ lower than the corresponding scenarios presented in WRIR 99-4122.

The lake extents for the Waubay Lakes Chain at the end of the dry-dry and wet-wet climatic scenarios, as well as the October 1,1999, and upper 1-percent probability lake levels (conditional analysis), are shown on plate 2 . The lake extents for the wet-wet climatic scenario are only slightly different than those presented in WRIR 99-4122. As on plate 1, the lake extents do not reflect areas that may be protected by dikes constructed near the city of Waubay during 1998.

Results from the lake-level frequency analysis were used to determine the probability of the five selected scenarios (wet-wet, wet-dry, average-average, dry-wet, and dry-dry). The conditional frequency analysis was performed for Waubay Lake using 10,000 simulated 16-year lake-level traces generated using the water mass-balance and stochastic time-series models and October 1, 1999, starting lake levels. The 0.2-, 1-, and 10-percent upper and lower probability bounds and the five 16-year traces generated for the selected scenarios for Waubay Lake are shown in figure 19. The five selected scenarios seem to represent essentially the full range of future lake levels. The lake levels after 16 years range from about the lower 1-percent probability bound for the dry-dry scenario, which corresponds to very dry conditions, to about the upper 0.2 -percent probability bound for the wet-wet scenario, which corresponds to very wet conditions. The average-average scenario is near the 50-percent probability bound after 16 years. 


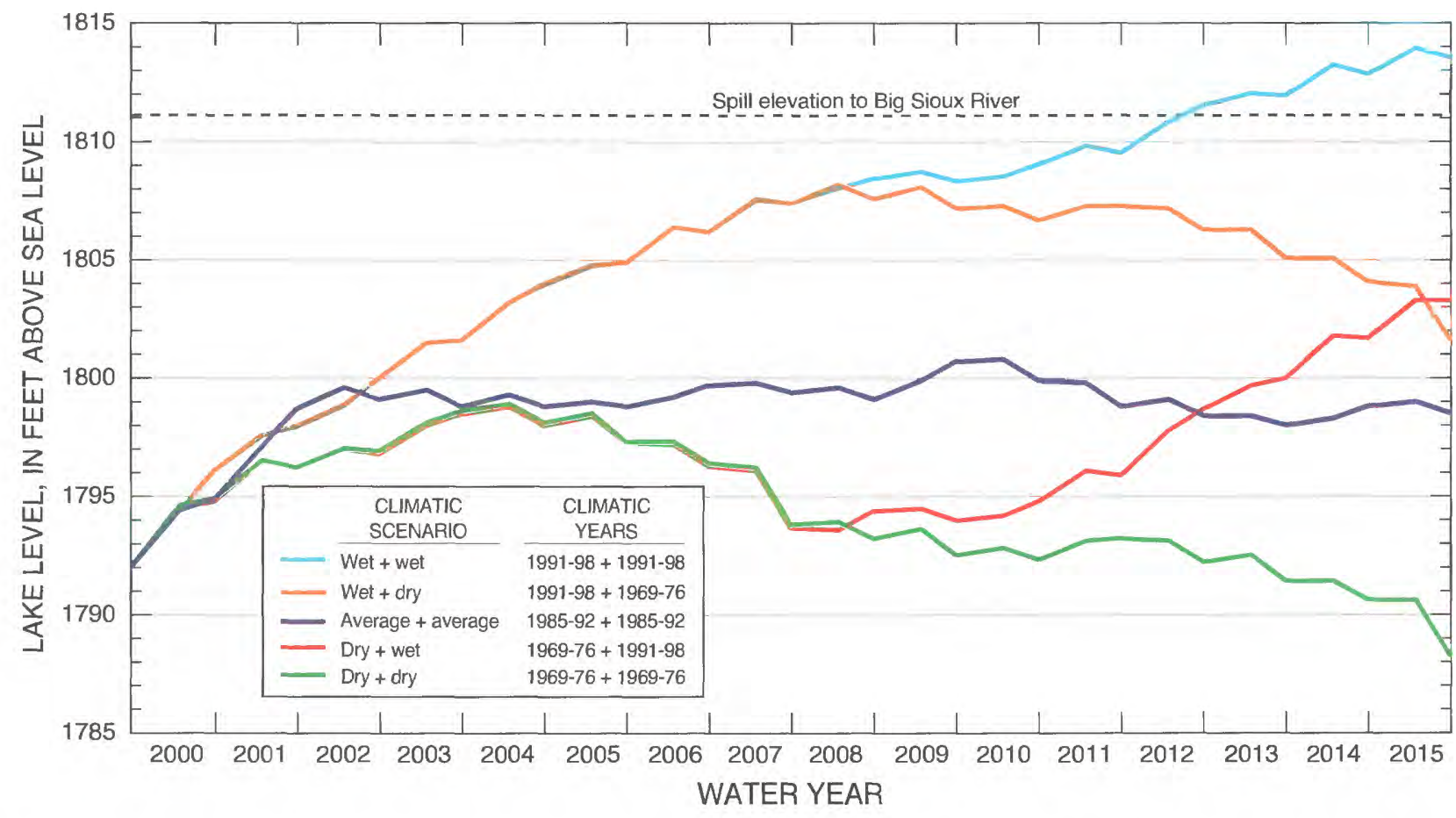

Figure 17. Simulated lake levels of Bitter Lake for selected 16-year climatic scenarios, starting with October 1, 1999, lake level and with the farm crossings removed at the outlet between Rush and Bitter Lakes.

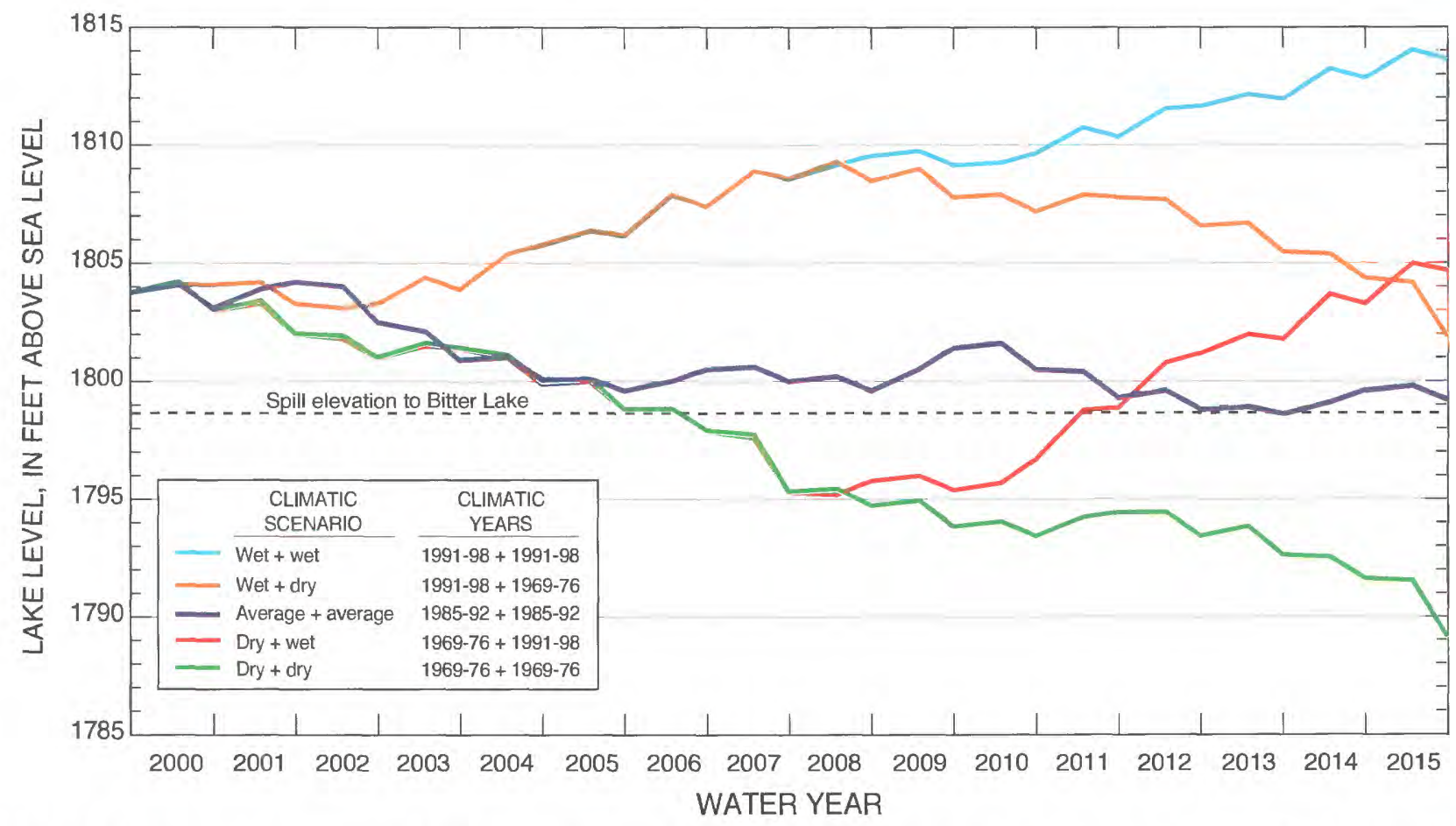

Figure 18. Simulated lake levels of Waubay Lake for selected 16-year climatic scenarios, starting with October 1, 1999, lake level and with the farm crossings removed at the outlet between Rush and Bitter Lakes. 


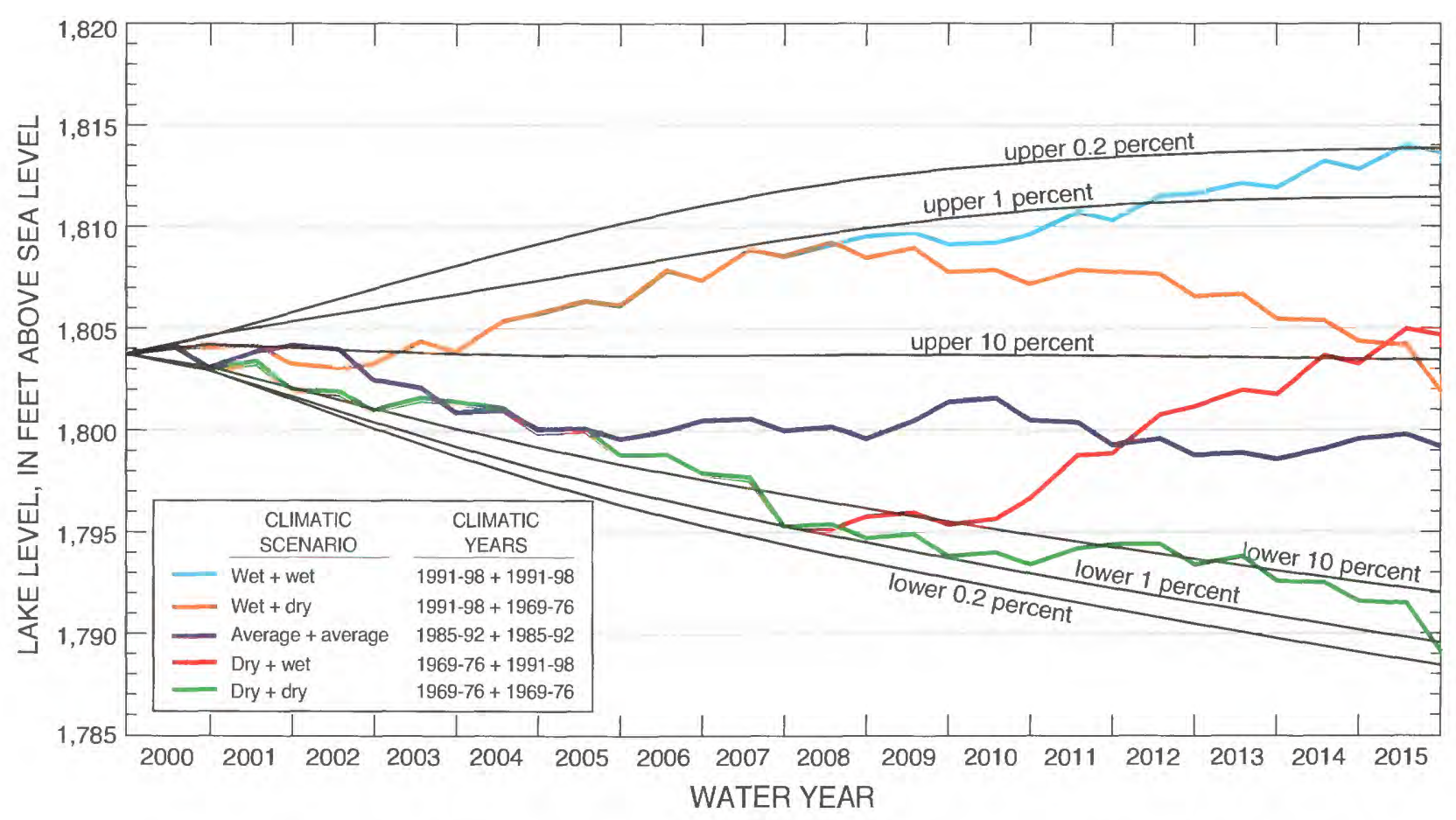

Figure 19. Probability bounds and selected 16-year scenario results for Waubay Lake, starting with October 1, 1999, lake level and with the farm crossings removed at the outlet between Rush and Bitter Lakes.

\section{SUMMARY}

A supplement to a USGS report, WRIR 99-4122, entitled "Lake-Level Frequency Analysis for the Waubay Lakes Chain, Northeastern South Dakota," was prepared to present lake-level frequency results for the Waubay Lakes Chain incorporating a modified outlet between Rush and Bitter Lakes. The modification involved removal of two farm crossings from the drainage way between Rush and Bitter Lakes during July-August 1999 as a result of a court ruling. Water mass-balance and stochastic time-series models were revised to incorporate the modified outlet and also to change the starting lake levels to October 1, 1999.

The outlet elevation between the upstream lakes (Hillebrands Lake, Rush Lake, Spring Lake, Swan Pond, and Waubay Lake) and Bitter Lake was changed from an elevation of 1,803.6 ft in WRIR 99-4122 to an elevation of $1,798.69 \mathrm{ft}$ to reflect the modified outlet between Rush and Bitter Lakes. Prior to July 1999, the outflow from Rush Lake through Little Rush Lake to Bitter Lake was by overtopping of two farm crossings. The Fifth Judicial Circuit Court ruled on July 6, 1999, that the two farm crossings be removed. Two 24-in. culverts through an east-west township road embank- ment now control outflow from Rush Lake to Bitter Lake. At higher lake levels, outflow from Rush Lake to Bitter Lake is controlled by a 42-in. culvert through the Burlington Northern Railroad embankment.

The U.S.Army Corps of Engineers supplied flow ratings between Rush and Bitter Lakes used in the water mass-balance model. The ratings are based on the assumption that the east-west township road is the control until the lake level reaches an elevation of $1,807.5 \mathrm{ft}$, when the railroad embankment becomes the control. It was assumed that the east-west township road will be maintained so that it is not breached.

Both an unconditional and a conditional lakelevel frequency analysis were done. An unconditional frequency analysis estimates the frequencies of high or low lake levels for a long time period during which the lake levels cycle many times between wet and dry periods. A conditional frequency analysis estimates the frequencies of hypothetical future lake levels for a relatively short time period, such as 50 years. Because studies that relate to flood-risk-assessment or floodmitigation alternatives usually are pertinent only for relatively short time periods into the future, conditional frequency analysis usually is more appropriate than unconditional frequency analysis. 
The unconditional frequency analysis was performed for Bitter, Enemy Swim, Pickerel, and Waubay Lakes using 10,000 years of generated lake levels with the farm crossings removed at the outlet between Rush and Bitter Lakes. The 1-percent exceedance level for Waubay Lake is at an elevation of $1,811.0 \mathrm{ft}$, which is approximately equal to the closed-basin spill elevation to the Big Sioux River. However, only nine separate spill events with an average duration of 11 years occurred during the 10,000-year simulation period, giving an average return period of 1,111 years. Therefore, because of the high serial persistence in the lake levels, the return period corresponding to the 1-percent exceedance level for Waubay Lake is much longer than 100 years. Bitter Lake exceeded an elevation of $1,814.0 \mathrm{ft}$, which is high enough to result in large flows to the Big Sioux River, an average of once every 2,500 years and stayed above this elevation an average of 5 years before subsiding. The exceedance-level results for Blue Dog Lake, Hillebrands Lake, Minnewasta Lake, Rush Lake, Spring Lake, and Swan Pond are nearly identical to those for Waubay Lake.

The unconditional frequency analysis also shows that the recent high levels of the Waubay Lakes Chain occur relatively infrequently. For example, the peak lake level of Waubay Lake was about an elevation of 1,802.1 ft in 1998 and 1999; however, based on model simulations, Waubay Lake only reaches this elevation an average of once every 154 years and stays above this elevation an average of 15 years before subsiding. Enemy Swim Lake reaches an elevation of 1,856.1 ft, which was exceeded in 1997, an average of once every 500 years and stays above this elevation an average of 1 year before subsiding. Pickerel Lake reaches an elevation of $1,846.7 \mathrm{ft}$, which was equalled in 1997 , an average of once every 500 years and stays above this elevation an average of 1 year before subsiding.

The average return periods for Enemy Swim and Pickerel Lakes for the 0.2-percent exceedance probabilities were 500 years, indicating that the extreme high lake levels of the smaller upstream lakes are caused by 1-year climatic extremes. However, the average return periods for Bitter and Waubay Lakes for the 0.2-percent exceedance probabilities are 2,500 years, indicating that the extreme high lake levels of the larger downstream lakes probably are caused by extreme climatic conditions lasting several years.

The frequencies for extreme low lake levels are difficult to accurately determine because small changes in lake volumes result in large changes in lake levels.
The lake levels of Enemy Swim, Pickerel, and Waubay Lakes in the 1930's and 1940's were very low compared to the long-term lake levels.

The conditional frequency analysis was performed for the 10 major lakes of the Waubay Lakes Chain using 10,000 simulated 50-year lake-level traces, each starting on October 1, 1999, with the farm crossings removed at the outlet between Rush and Bitter Lakes. The generated data can be used to estimate the probability of virtually any event that involves future lake levels.

The upper 1-percent probability bound (conditional analysis) for Waubay Lake rises quickly to a nearly constant level at an elevation of about $1,811 \mathrm{ft}$, which corresponds to the unconditional 1-percent exceedance level. Therefore, the chance that Waubay Lake will continue to rise to the spill elevation with the Big Sioux River within the next 10 to 15 years is greater than 1 percent. The lower 1-percent probability bound (conditional analysis) for Waubay Lake falls slowly during the next 50 years. The lower 1-percent probability bound is at elevation $1,785 \mathrm{ft}$ in 2024 , indicating that there is about a 1-percent chance Waubay Lake will return to levels comparable to historic 1960-92 levels in the next 25 years. Also, Waubay Lake is unlikely to return to levels comparable to those during the extreme drought of the 1930's for much longer than 50 years.

The upper 10-percent probability bound (conditional analysis) for Bitter Lake with the farm crossings removed at the Rush-Bitter outlet increases about $10 \mathrm{ft}$ during water years 1999-2010 and then slowly decreases, and the upper 1-percent probability bound increases about $19 \mathrm{ft}$ during water years 1999-2015 and then becomes nearly constant at an elevation of about $1,810 \mathrm{ft}$. The chance that the level of Bitter Lake will continue to rise to the spill elevation with the Big Sioux River within the next 15 to 20 years is greater than 1 percent. Conversely, the lower 10-percent probability bound for Bitter Lake decreases about $9 \mathrm{ft}$ during water years 1999-2025 and then slowly decreases to about an elevation of $1,780.5 \mathrm{ft}$ by the end of water year 2049. Furthermore, the lower 1-percent probability bound decreases about $11 \mathrm{ft}$ by the end of water year 2025 and then slowly decreases to about an elevation of $1,777.5 \mathrm{ft}$ by the end of water year 2049. Therefore, there is about a 1-percent chance that Bitter Lake will return to levels comparable to historic 1960-92 levels in the next 50 years. 
The conditional frequency results for Blue Dog Lake, Hillebrands Lake, Minnewasta Lake, Rush Lake, Spring Lake, Swan Pond, and Waubay Lake with the farm crossings removed at the Rush-Bitter outlet indicate the upper 10-, 1-, and 0.2-percent probability bounds are about the same for all seven lakes because the lakes are joined at these lake levels. The upper 10-percent probability bounds are constant until water year 2010, then slowly decrease, and the upper 1 -percent probability bounds increase about $8 \mathrm{ft}$ from the current level and reach an elevation of $1,811.5 \mathrm{ft}$ in 2015. The upper 0.2-percent probability bounds for Bitter and Rush Lakes become about equal after 2010 because enough water spills from Rush Lake to fill Bitter Lake to the extreme high levels of Rush Lake. As with Waubay Lake, the conditional frequency analysis for Blue Dog Lake, Hillebrands Lake, Minnewasta Lake, Rush Lake, Spring Lake, and Swan Pond indicates that the chance the lakes will continue to rise to the spill elevation with the Big Sioux River within the next 10 to 15 years is greater than 1 percent.

The lower probability bounds (conditional analysis) for Hillebrands Lake, Minnewasta Lake, Spring Lake, Swan Pond, and Waubay Lake are similar, with each bound decreasing slowly during the entire 50-year simulation. There is about a 1-percent chance that Hillebrands Lake, Spring Lake, Swan Pond, and Waubay Lake will decrease to 1960-92 levels in the next 25 years. However, the lower probability bounds for Blue Dog and Rush Lakes become nearly constant in year 2010 and beyond and indicate that there is about a 10-percent chance that Blue Dog and Rush Lakes could return to historic 1960-92 levels within 10 years.

The frequency results for Enemy Swim and Pickerel Lakes are totally unaffected by the removal of the farm crossings at the outlet between Rush and Bitter Lakes. Because Enemy Swim and Pickerel Lakes spill frequently and never join with the downstream lakes, the upper probability bounds (conditional analysis) for both lakes remain nearly constant for the entire simulation period. Therefore, levels of both lakes are unlikely to increase significantly over current levels, and both lakes could return to historic 1960-92 levels much sooner than the other lakes under a reversal of the current wet conditions.

The climatic scenarios analysis summarized in WRIR 99-4122 also was revised to account for the removal of the farm crossings at the outlet between Rush and Bitter Lakes. The starting lake levels used in the revised climatic scenarios represent October 1, 1999, levels.

The wet-wet scenario, representing two 1991-98 climatic segments, results in Bitter Lake, after 16 years, rising $21.4 \mathrm{ft}$ above the starting lake level and Waubay Lake rising $9.8 \mathrm{ft}$. When an 8-year wet segment (1991-98) is combined with an 8-year dry segment (1969-76), Bitter Lake, after 16 years, rises $9.5 \mathrm{ft}$ above the starting lake level, and Waubay Lake declines $1.9 \mathrm{ft}$. Under the dry-wet scenario, Bitter Lake rises $11.2 \mathrm{ft}$ and Waubay Lake rises $0.90 \mathrm{ft}$, while under the dry-dry scenario, Bitter Lake declines $3.9 \mathrm{ft}$ and Waubay Lake declines $14.7 \mathrm{ft}$.

The conditional frequency analysis performed for Waubay Lake with October 1, 1999, starting lake levels was compared to the scenario results. The five selected scenarios seemed to represent essentially the full range of hypothetical future lake levels. The lake levels after 16 years range from about the lower 1-percent probability bound for the dry-dry scenario to about the upper 0.2-percent probability bound for the wet-wet scenario. The average-average scenario is near the 50-percent probability bound after 16 years.

\section{SELECTED REFERENCES}

Niehus, C.A., Vecchia, A.V., and Thompson, R.F., 1999, Lake-level frequency analysis for the Waubay Lakes Chain, northeastern South Dakota: U.S. Geological Survey Water-Resources Investigations Report 99-4122, 166 p., 2 pls.

U.S. Department of Commerce, 1950-99, Monthly climatological data, South Dakota: Asheville, North Carolina.

Wiche, G.J., and Vecchia, A.V., 1996, Lake-level frequency analysis for Devils Lake, North Dakota: U.S. Geological Survey Water-Supply Paper 2469, 57 p. 